\title{
Hyperpycnal (over density) flows and deposits
}

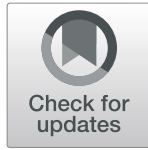

Carlos Zavala ${ }^{1,2}$ (D)

\begin{abstract}
A hyperpycnal flow forms when a relatively dense land-derived gravity flow enters into a marine or lacustrine water reservoir. As a consequence of its excess of density, the incoming flow plunges in coastal areas, generating a highly dynamic and often long-lived dense underflow. Depending on the characteristics of the parent flow (flow duration and flow rheology) and basin salinity, the resulting deposits (hyperpycnites) can be very variable.

According to flow duration, land-derived gravity flows can be classified into short-lived or long-lived flows. Shortlived gravity flows last for minutes or hours, and are mostly related to small mountainous river discharges, alluvial fans, collapse of natural dams, landslides, volcanic eruptions, jökulhlaups, etc. Long-lived gravity flows last for days, weeks or even months, and are mostly associated with medium- to large-size river discharges.

Concerning the rheology of the incoming flow, hyperpycnal flows can be initiated by non-Newtonian (cohesive debris flows), Newtonian supercritical (lahars, hyperconcentrated flows, and concentrated flows) or Newtonian subcritical flows (pebbly, sandy or muddy sediment-laden turbulent flows). Once plunged, non-Newtonian and Newtonian supercritical flows require steep slopes to accelerate, allow the incorporation of ambient water and develop flow transformations in order to evolve into a turbidity current and travel further basinward. Their resulting deposits are difficult to differentiate from those related to intrabasinal turbidites. On the contrary, long-lived Newtonian subcritical flows are capable of transferring huge volumes of sediment, freshwater and organic matter far from the coast even along gentle or flat slopes. In marine settings, the buoyant effect of interstitial freshwater in pebbly and sandy hyperpycnal flows can result in lofting due to flow density reversal. Since the excess of density in muddy hyperpycnal flows is provided by silt-clay sediments in turbulent suspension, lofting is not possible even in marine/saline basins. Muddy hyperpycnal flows can also erode the basin bottom during their travel basinward, allowing the incorporation and transfer of intrabasinal sediments and organic matter. Long-lived hyperpycnal flow deposits exhibit typical characteristics that allow a clear differentiation respect to those related to intrabasinal turbidites. Main features include (1) composite beds with gradual and recurrent changes in sediment grain-size and sedimentary structures, (2) mixture of extrabasinal and intrabasinal components, (3) internal and discontinuous erosional surfaces, and (4) lofting rhythmites in marine/saline basins.
\end{abstract}

Keywords: Hyperpycnal flows, Hyperpycnites, Turbidites, Sediment gravity flows

\section{Introduction}

River discharges are largely the most efficient mechanism for transferring sediments from production areas into related marine and lacustrine basins. Syvitski et al. (2003) demonstrated that present rivers contribute $89 \%$

Correspondence: czavala@uns.edu.ar

'Departamento de Geología, Universidad Nacional del Sur, San Juan 670,

8000 Bahía Blanca, Argentina

${ }^{2}$ GCS Argentina SRL, Molina Campos 150, 8000 Bahía Blanca, Argentina of terrigenous sediments entering the ocean. Sediments transported by rivers are mostly accumulated in deltas. Bates (1953) introduced a rational classification of deltas, considering the relationship between the density of the incoming river discharge $(D r)$ respect to that of the water in the reservoir $(D w)$. Bates recognized three categories, termed hypopycnal flow, homopycnal flow and hyperpycnal flow (Fig. 1).
SpringerOpen (c) The Author(s). 2020 Open Access This article is licensed under a Creative Commons Attribution 4.0 International License, which permits use, sharing, adaptation, distribution and reproduction in any medium or format, as long as you give appropriate credit to the original author(s) and the source, provide a link to the Creative Commons licence, and indicate if changes were made. The images or other third party material in this article are included in the article's Creative Commons licence, unless indicated otherwise in a credit line to the material. If material is not included in the article's Creative Commons licence and your intended use is not permitted by statutory regulation or exceeds the permitted use, you will need to obtain permission directly from the copyright holder. To view a copy of this licence, visit http://creativecommons.org/licenses/by/4.0/. 

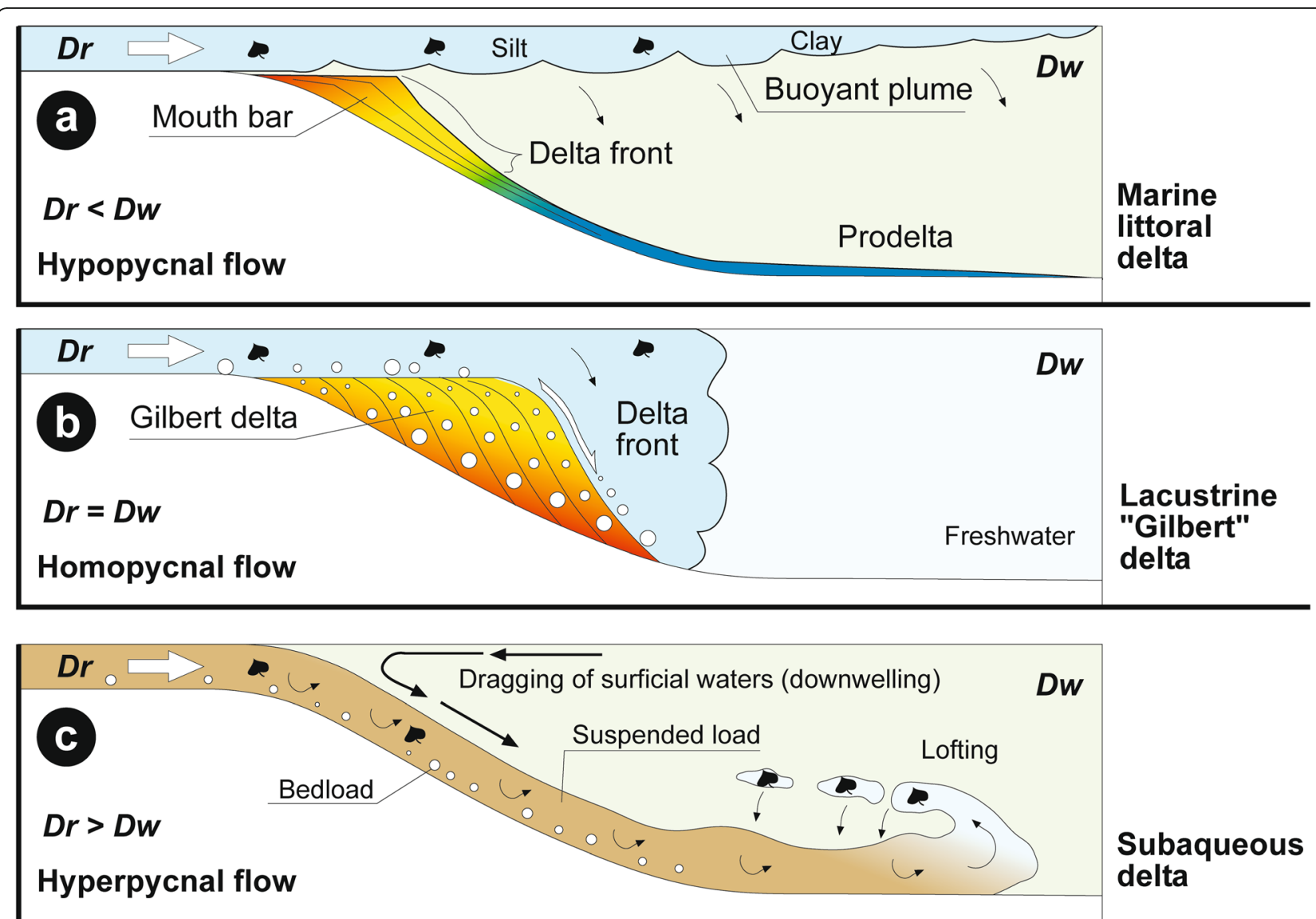

Fig. 1 Origin of hypopycnal (a), homopycnal (b) and hyperpycnal (c) flows as a result of the density contrast between river discharge and basin waters. Note in $\mathbf{c}$ that the excess in density is provided by sediments in turbulent suspension. Modified from Zavala and Pan 2018

A hypopycnal flow (Fig. 1a) forms when the river discharge is less-dense respect to the density of the water in the reservoir $(D r<D w)$. In this situation the incoming flow experienced a rapid deceleration and loss of confinement at the river mouth, with the consequent accumulation of coarse-grained fractions in mouth bars. Freshwater, suspended fine-grained materials (silt/ clay) and plant remains form a buoyant plume that can extend some distance from the coastline. The collapse of these materials composes a fine grained prodelta. The typical result of hypopycnal flows are marine and eventually lacustrine littoral deltas.

A homopycnal flow (Fig. 1b) forms when the incoming flow has a similar density respect to that of the receiving water body $(D r=D w)$. In this situation all the transported sediment fractions rapidly collapse at the river mouth, forming steep-gradient deltas (Gilbert-type deltas) dominated by avalanches. The homopycnal condition is almost exclusive of sediment-free bedload dominated stream flows entering freshwater lakes.

Finally, a hyperpycnal flow (Fig. 1c) occurs when the density of the incoming flow is higher than that of the water in the reservoir $(D r=D w)$. During floods, the suspended sediment concentration in river discharges can substantially rise (Mulder et al. 2003), resulting in mixtures of water and sediments with a bulk density that can largely exceed that of the receiving water body (marine or lacustrine). In that situation the incoming flow can plunge in coastal areas resulting in a river generated underflow (or hyperpycnal flow). Hyperpycnal flows generated from river discharges and their deposits, hyperpycnites (Mulder et al. 2003), have received an increasing attention during recent years. The most accepted version of a typical hyperpycnite is a fine-grained deposit characterized by a coarsening and then fining upward bed, reflecting an increasing and then decreasing magnitude in the fluvial-related discharge (Mulder and Alexander 2001). Nevertheless, hyperpycnal flow deposits can be largely more complex (Zavala 2018).

A common mistake is to simply try to classify a hyperpycnal flow as a type of sediment gravity flow, in an attempt to define its rheology and flow mechanics. Nevertheless, the definition of a hyperpycnal flow is not necessarily related to flow composition, density or rheology. A hyperpycnal flow is defined according to the 
density-contrast at the coast line between that of an incoming land-derived relatively dense flow and that of the water in a water body reservoir. This situation is possible not only for conventional rivers discharges, but also for a wide range of relatively dense flows originated on land (Zavala 2018). Depending on climate and coastal geomorphology, these flows can be highly variable in terms of density and duration.

With the scope of simplifying the current terminology, Feng (2019) recently proposed to replace the Greek terms "hypopycnal", "homopycnal" and "hyperpycnal" by "lower density", "equal density" and "over density" respectively. The last proposal can be especially useful for Chinese geoscientists, since it facilitates the understanding of the truly meaning of the original concept of Bates (1953).

\section{Methods}

This paper explores the different types of land derived (non-volcanic) sediment gravity flows and the characteristics of their related hyperpycnal flows and deposits when entering marine and lacustrine basins. It synthetizes observations and interpretations performed during more than 30 years of research on sediment gravity flows and their deposits. The understanding and examples provided in this work were obtained during extensive field works carried out in different basins of Argentina, Colombia, Brazil, Venezuela, Trinidad \& Tobago, Mexico, Cuba, Spain, Italy, Russia and China.

Main interpretations introduced in this paper are based on facies and process-oriented analysis, supported by flume experiments and modern analogues. Following Teichert (1958) a sedimentary facies can be defined as the sum of all primary macroscopic characteristics of a sedimentary body of rock that are relevant for understanding the hydrodynamic conditions (sedimentary processes) active during its deposition. When supported by flume experiments, facies analysis constitutes a comprehensive method for reading sedimentary processes in sedimentary rocks. Additionally, process-oriented analysis allows to track the step-by-step evolution of sedimentary processes on single and internally complex sedimentary bodies. At present, facies analysis continues to be a revolutionary and useful tool for sedimentological analysis. Reading sedimentary processes on fossil rocks is not an easy task and requires a positive combination of deep understanding and imagination.

\section{Results}

\subsection{Types of land-derived dense flows}

Depending on the relief, climate and type of available sediment, land areas can generate a wide spectrum of flows having different duration and bulk density.

According to the duration of land generated flows, these can be classified into short-lived or long-lived flows (Fig. 2). Short-lived flows last for minutes or hours, and are mostly related to discharges of small mountainous rivers, alluvial fans, collapse of natural dams, landslides, volcanic eruptions, jökulhlaups, etc. Long-lived flows last for days, weeks or even months, and are mostly associated with medium- to large-size rivers with extensive catchment areas.

Concerning the density of land-derived flows, these can range from cohesive debris flows up to clear water discharges. Of special interest for the initiation of hyperpycnal flows are mixtures of water and sediment (also known as sediment gravity flows) since they can achieve the required bulk density to exceed that of the receiving water body at coastal areas. In their seminal paper, Middleton and Hampton (1973) defined a sediment gravity flow as the "flow of sediments or sediment-fluid mixtures under the action of gravity". These flows are distinguished from fluid gravity flows (or streamflows), in which a fluid is moved by gravity and the sediment is passively dragged by shear forces provided by the passing-by flow. Although a sediment gravity flow can be subaqueous or subaerial in origin, in subaerial environments a flow can be classified as a sediment gravity flow only if gravity acting on sediment is the main driving force. As an example, in subaerial environments a turbulent flow with sediment concentration below the Bagnold's limit (9\% vol) (Bagnold 1962) should be classified as a fluid gravity flow, since gravity acting on the fluid (water) is the main contribution to flow movement. Nevertheless, a similar turbulent flow in a subaqueous environment will fall into the category of a sediment gravity flow. A particular situation happens when longlived river-generated hyperpycnal flows are considered. These flows are originated and sustained by the continuous "pumping" from the related fluvial system, and will be maintained as long as the fluvial discharge continues. For this reason, hyperpycnal flows cannot be considered neither fluid nor sediment gravity flows, but simply "gravity flows", since gravity acts on the flow running along the entire (fluvial - hyperpycnal) system as a whole.

Middleton and Hampton (1973) recognized four categories of sediment gravity flows according to their dominant sediment support mechanism: (1) debris flows (sediments supported by matrix strength), (2) grain flows (sediments supported by grain-to-grain interactions), (3) fluidized flows (sediments supported by escaping fluids), and (4) turbidity currents (sediments supported by flow turbulence). The use of this classification in fossil deposits is unpractical, since geologists has to deal with the final product where sediment support mechanisms and sedimentary processes are no always evident from the final product or deposit (see comments in Smith 1986) and should be inferred from the analysis of fabric, texture, and sedimentary structures (if any). Other classifications (Beverage and Culbertson 1964; Middleton 


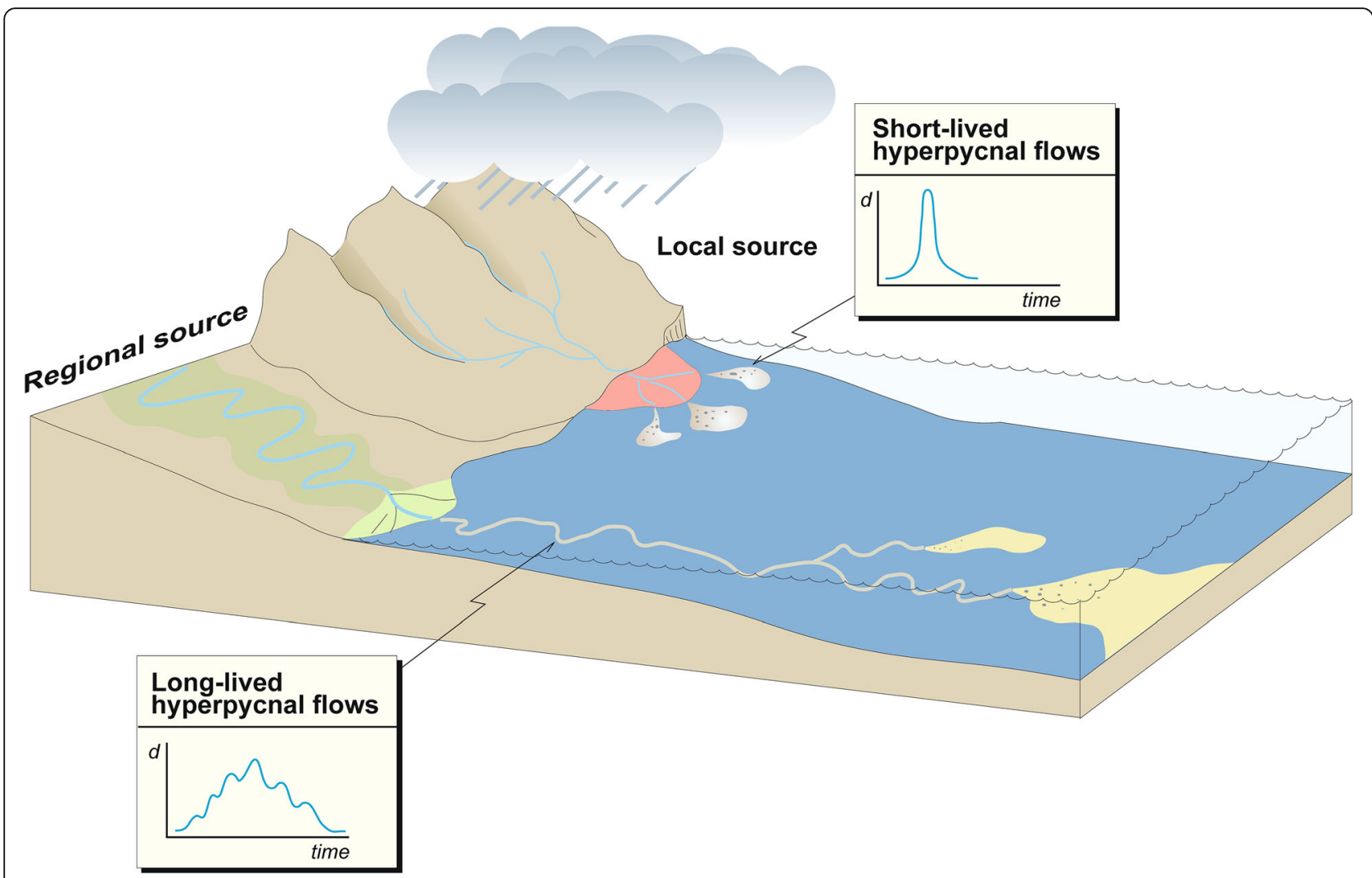

Fig. 2 Types of hyperpycnal flows generated by short-lived and long-lived discharges

1967) focus on the original flow density, another difficult parameter to evaluate from fossil deposits. As a consequence, the recognition and classification of sediment gravity flows and their deposits is highly controversial and have been strongly debated during recent years (see reviews in Mulder and Alexander 2001; Dasgupta 2003). The main problem probably resides in trying to apply to a rock a classification specially designed for flows.

It is not the intention of these notes to discuss the classification of sediment gravity flows. With the scope of simplifying the analysis of ancient deposits, a simpler classification of sediment gravity flows (Fig. 3) based on Mutti (1992), Mutti et al. (1999) and Mulder and Alexander (2001) concepts is here proposed. Four categories of sediment gravity flows are recognized, based on the analysis of the primary characteristics of their related final deposits: (1) cohesive debris flows (CDF), (2) hyperconcentrated flows (HCF), (3) concentrated flows (CF), and (4) sediment-laden turbulent flows (SLTF). The term "sediment-laden turbulent flows" is preferred instead of "turbidity currents" because the etymology of the last refers to "turbid flows", and not specifically to "turbulent flows". The proposed classification has several advantages since (1) it is strongly based on macroscopic physical characteristics that can be directly observed in the deposits, like texture, fabric, grading and sedimentary structures, and (2) it is applicable to both subaerial and subaqueous environments (turbidity currents are mostly recognized in subaqueous environments).

Due to their relative high density and related inertia, landgenerated sediment gravity flows commonly do not form conventional littoral delta deposits (Fig. 1a) when entering a marine or lacustrine basin, but plunge and transform into different types of hyperpycnal flows. From a rheological standpoint, hyperpycnal flows can be initiated from nonNewtonian (cohesive debris flows), Newtonian supercritical (lahars, hyperconcentrated flows, and concentrated flows) or Newtonian subcritical flows (pebbly, sandy or muddy SLTF).

There is an evident direct relationship between source area relief and resulting flow types (Figs. 2 and 4). The triggering and downslope advance of cohesive debris flows require steep slopes to overcome the internal cohesion provided by matrix strength, otherwise the flow will stop due to cohesive freezing. In a similar way supercritical flows need steep slopes to accelerate, incorporate new sediment and water, and transform potential energy into kinetic energy. In this type of flow, steep slopes are required to keep flow velocity high in order to overcome the energy loss caused by grain-tograin collision. In consequence, hyperpycnal flows triggered by cohesive debris flows and supercritical flows are always associated with relatively high relief coastal areas. 


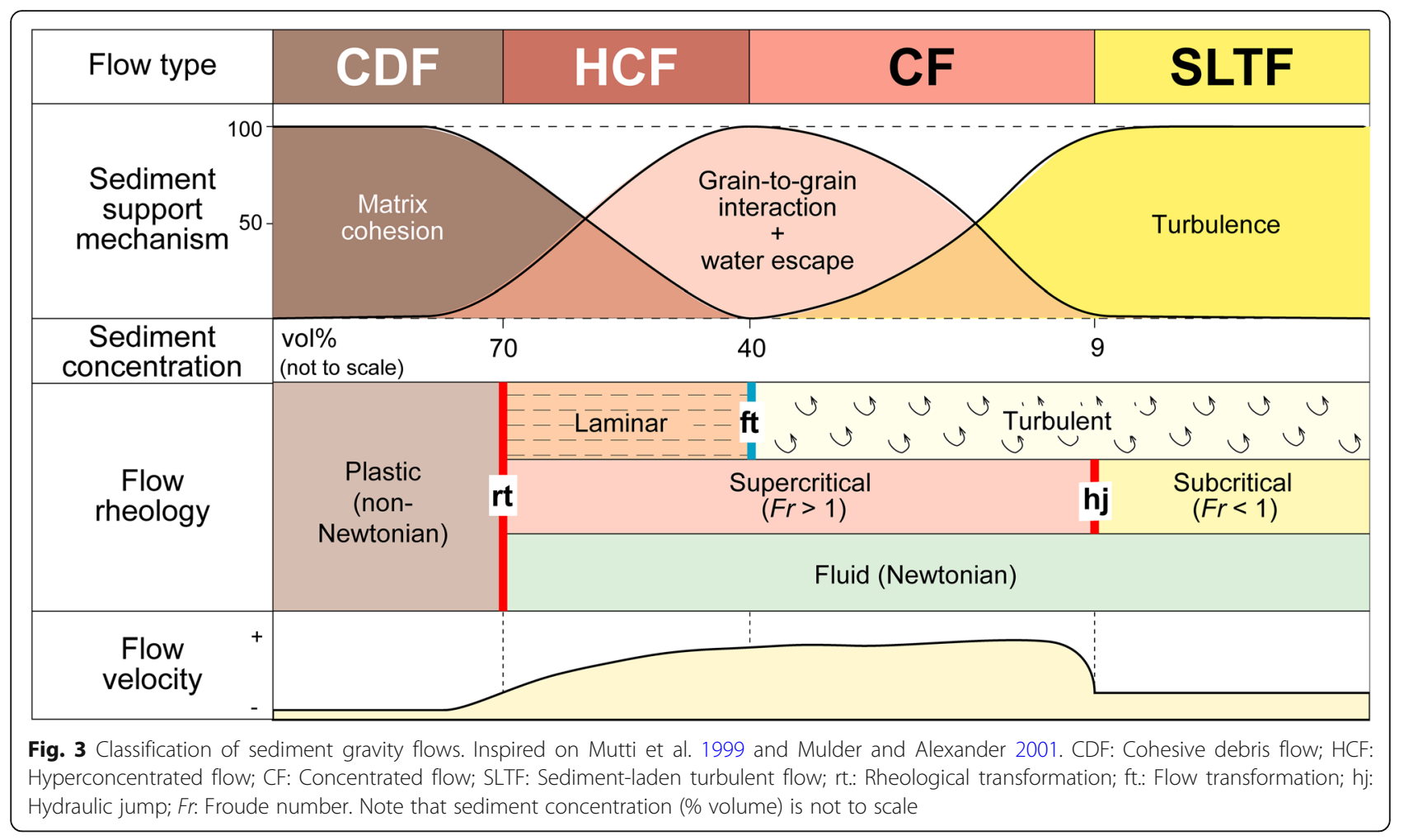

\begin{tabular}{|c|c|c|c|c|c|c|}
\hline \multicolumn{6}{|c|}{ Types of hyperpycnal flows } & Flow origin \\
\hline \multicolumn{3}{|c|}{$\begin{array}{l}\text { Non-Newtonian } \\
\text { (plastic) }\end{array}$} & \multirow{2}{*}{\multicolumn{2}{|c|}{$\begin{array}{c}\text { Cohesive } \\
\text { debris flows } \\
\text { (CDF) } \\
\text { Hyperconcentrated } \\
\text { flows } \\
\text { (HCF) }\end{array}$}} & $\begin{array}{l}10,0,0,0 \\
0,00,0,0,0 \\
100,0,0\end{array}$ & \multirow{3}{*}{$\begin{array}{l}\text { High-density short-lived flows } \\
\text { entering the basin } \\
\text { - Alluvial fans } \\
\text { - Small mountanious rivers } \\
\text { - Flash floods } \\
\text { Require steep slopes to accelarate, incorporate } \\
\text { ambient water, and transform into dilute turbulent } \\
\text { flows }\end{array}$} \\
\hline \multirow{5}{*}{ 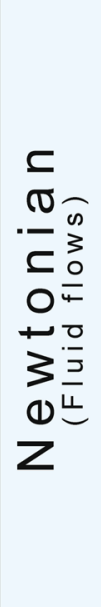 } & \multirow{2}{*}{ 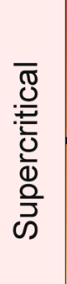 } & : & & & & \\
\hline & & \multirow{4}{*}{ 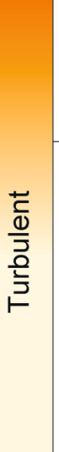 } & \multicolumn{2}{|c|}{$\begin{array}{l}\text { Concentrated } \\
\text { (granular) flows } \\
\text { (CF) }\end{array}$} & $\sim$ SLTF & \\
\hline & \multirow{3}{*}{ 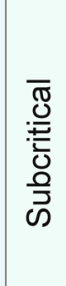 } & & \multirow{3}{*}{ 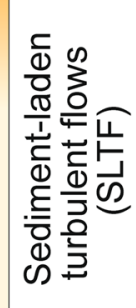 } & Pebbly & 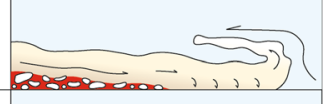 & \multirow{3}{*}{$\begin{array}{l}\text { Low-density long-lived flows } \\
\text { entering the basin } \\
\text { - Medium- to large-size rivers } \\
\text { No steep slopes are neccesary. Flow can travel } \\
\text { for long distances since the flow is sustained by } \\
\text { the river discharge }\end{array}$} \\
\hline & & & & Sandy & 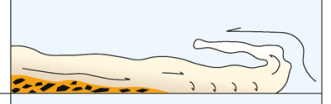 & \\
\hline & & & & Muddy & & \\
\hline
\end{tabular}


SLTF can be generated both in high- and low-gradient settings. High gradient SLTF are rare, and often related to short-lived surge-like flows associated with small mountainous rivers. These episodic turbulent flows usually do not form important deposits, since the sediment concentration in these diluted flows is relatively low. Owing to its poor significance, these episodic flows and their deposits are not going to be discussed in this paper. On the contrary, low gradient SLTF are commonly associated with medium to large size rivers, where the flow is driven by long lived fluvial discharges sustained for days or even months. Due to the relative low sediment concentration in SLTF, only long-lived SLTF can accumulate important hyperpycnal flow deposits. When entering a basin, long-lived SLTF can result in pebbly, sandy or muddy hyperpycnal flows, mostly depending on the grain size of the turbulent suspension in the associated river discharges and the existence or not of extrabasinal bedload (Fig. 4). The characteristics of the different types of land derived sediment gravity flows and their associated deposits will be discussed in the following sections.

\subsection{Cohesive debris flows and their resulting deposits}

Cohesive debris flows (CDF) are very high-density flows having a plastic (non-Newtonian) rheology. The concentration limits for cohesive debris flows have been intensively debated (Beverage and Culbertson 1964; Li et al. 1983; Costa 1984, 1986; Pierson and Costa 1987; Coussot and Meunier 1996; Mulder and Alexander 2001; Dasgupta 2003; Pierson 2005). One of the key points to understand these departures resides in the nature of the interstitial material that provides cohesion, which largely depends on composition (e.g. type of clay) and grain size (Baker et al. 2017). Following Mulder and Alexander (2001) a lower concentration limit of $70 \%$ by volume is considered for cohesive debris flows in this paper (Fig. 3). These flows are characterized by an internal cohesion provided by a muddy interstitial matrix. Since internal cohesion is the main grain support mechanism, these flows can transport a wide range of textural elements (up to giant blocks) floating in a muddy matrix. Deposition of these flows occurs by cohesive "freezing" when the applied shear stress falls below the internal yield strength threshold (Prior et al. 1984; Mulder and Cochonat 1996). When entering a marine or lacustrine basin these high-density flows can result in primary CDF deposit (facies F1 of Mutti 1992), or they can transform into more diluted flows by acceleration and entrainment of ambient water (Fig. 5).

1) Primary hyperpycnal cohesive debris flow deposits result from cohesive freezing, and can be eventually recognized by a highly immature fabric containing light extrabasinal components like charcoal clasts, pieces of wood and leaves (Fig. 6). If the parent flow does not have these components the differentiation from intrabasinal cohesive debris flow deposits could be very difficult or even impossible. Primary deposits usually accumulate in gentle slope areas located close to high gradient source areas (typically at the lower slope of alluvial fans).

2) In high gradient subaqueous environments cohesive debris flows can accelerate, entrain ambient water, and transform from plastic into fluid (rheological transformation, Fig. 3). Due to their muddy matrix, cohesive debris flows are poorly permeable and consequently water entrainment could be limited. Nevertheless, water entrainment could be favoured by hydroplaning (Mohrig et al. 1998), since in this situation water can be incorporated from the flow bottom. If a cohesive debris flow incorporates water and dilutes, it could transform into a hyperconcentrated flow (inertia-dominated laminar flow) through a rheological transformation (Mutti 1992). Due to the loss of internal cohesion, this transformation will

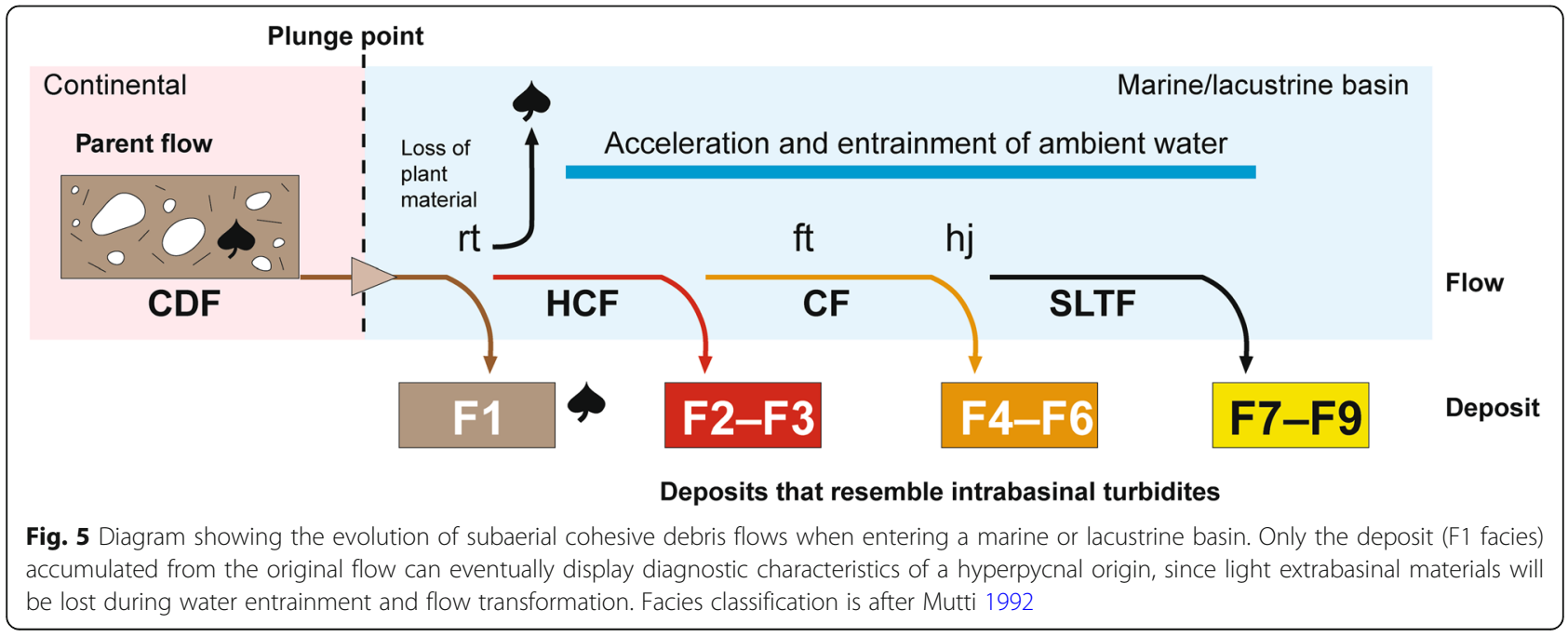




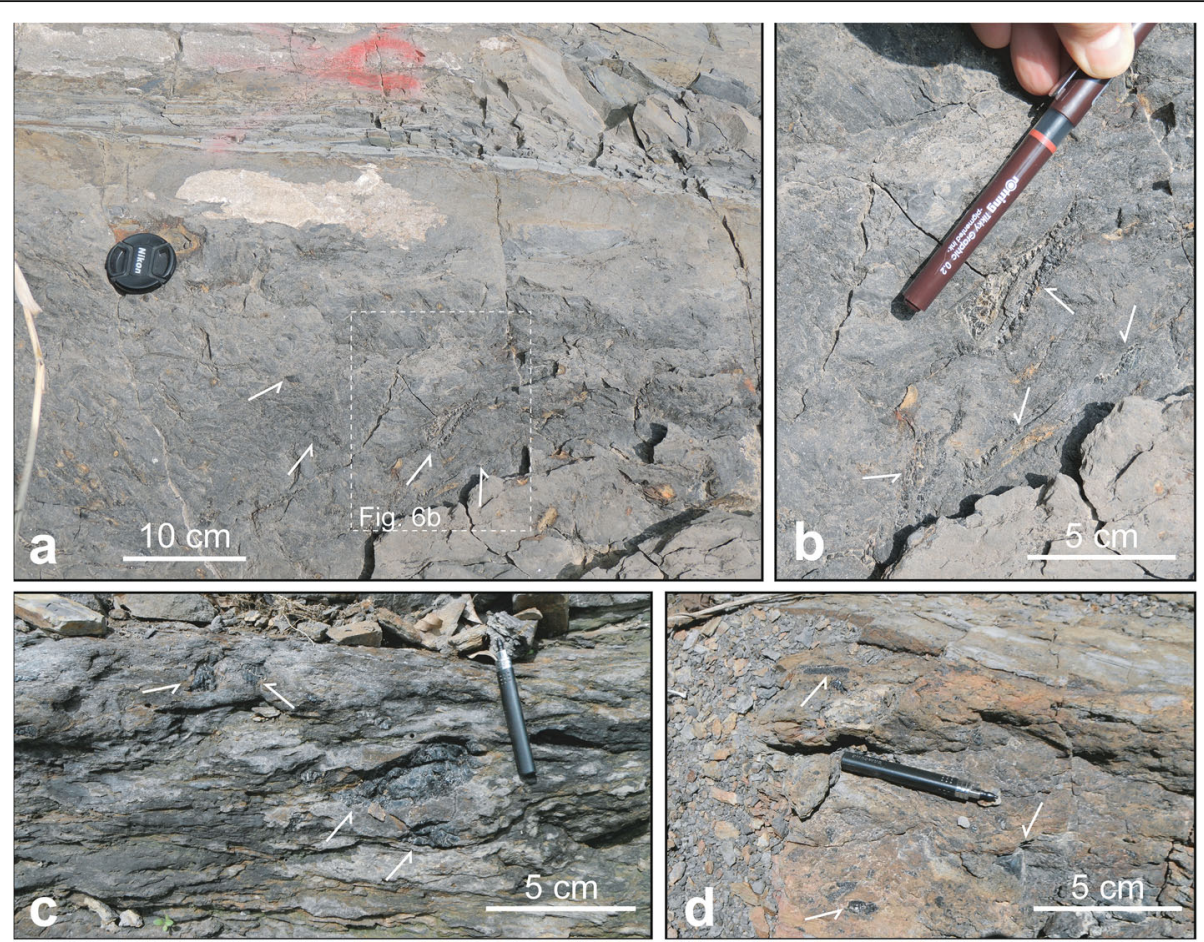

Fig. 6 Examples of deposits related to extrabasinal cohesive debris flows (facies F1 of Mutti 1992). a Mud-rich, poorly sorted deposits with abundant, dispersed, large plant fragments (arrows). Deep-water deposits from the Cretaceous of Lingshan Island, China; b Detail of a. Note large plant remains and charcoal fragments (arrows); c, d Matrix-supported, muddy conglomerate with large plant remains and charcoal clasts (arrows). Deep-water deposits from the Eocene Guarico Formation, Venezuela

result in the segregation of the coarsest grain-size fraction (typically boulders and cobbles) that cannot be more supported due to the limited cohesion and increasing grain-to-grain interaction (Mutti 1992). This dilution implies no only and incorporation of ambient water, but also the progressive washing-out of the silt-clay fraction constituting the former muddy matrix (Zavala et al. 2012). This step is crucial for the exclusion of light extrabasinal materials, since plant materials will be segregated from the main flow and incorporated in the slow-moving diluted turbulent cloud developed towards the flow tail (flow bipartition in the sense of Sanders (1965) and Mutti et al. (1999)). Consequently, the resulting hyperconcentrated flow can eventually freeze (due to frictional freezing) with the accumulation of F2 facies (F2 facies of Mutti 1992, Fig. 5) or can transform into concentrated and finally sediment-laden turbulent flows through a series of flow transformations and hydraulic jumps. It is remarkable that all these facies will be very similar to the extrabasinal facies included in the Mutti's 1992 facies tract (F3 to F9, Fig. 5). Due to the lack of plant debris and an origin associated to surge like flows, these last deposits can be easily confused with those generated by intrabasinal turbidites.

Some examples of deposits accumulated by extrabasinal cohesive debris flows are shown in Fig. 6. As previously discussed, the recognition of extrabasinal CDF deposits is facilitated by the presence of extrabasinal light components like large pieces of wood, leaves and charcoal.

\subsection{Hyperconcentrated flows and their resulting deposits}

Hyperconcentrated flows (HCF) are inertia-dominated (subcritical) laminar flows characterized by a high sediment concentration (Beverage and Culbertson 1964; Pierson and Scott 1985; Costa 1986; Pierson and Costa 1987; Batalla et al. 1999; Pierson 2005; Nemec 2009). These flows represent a transition between a plastic and a fluid rheology (Mutti et al. 1996), since they retain some cohesion from matrix strength which is progressively replaced by grain-to-grain interaction and water escape support mechanism (Fig. 3). Pierson and Costa (1987) considered for hyperconcentrated flows a sediment concentration ranging between $20 \%$ and $60 \%$ in volume. Nevertheless, as in cohesive debris flows, these boundary limits can be variable depending on grain size and composition. Following Mulder and Alexander (2001) in this paper is considered for HCF a sediment concentration ranging between $70 \%$ and $40 \%$ in volume. One of the consequences of a lower cohesion is an increase in flow velocity, resulting in faster and largely more dangerous flows respect to cohesive debris flows. 
The movement of different flow laminas is facilitated by trapped waters. In these inertia-dominated flows, water is incorporated at the lower flow boundary and try to escape along the flow column, providing an additional fluid-escape support mechanism (Middleton and Hampton 1973). The loss of matrix cohesion as the dominant sediment support mechanism limited the maximum size of individual elements that can be transported by the flow, and consequently hyperconcentrated flow deposits are relatively better sorted than cohesive debris flow deposits.

The occurrence of hyperpycnal HCF and their deposits is typical of high gradient settings, located close to source areas. Steep slopes are required to maintain the velocity and the related inertia of this high-density flow. If flow velocity is progressively reduced when entering a basin, hyperpycnal HCF can accumulate subaqueous primary deposits by frictional freezing, characterized by mud-rich coarse-grained deposits with extrabasinal light components (Figs. 7 and 8) like charcoal clasts, wood and plant remains (facies F2 of Mutti 1992; Fig. 7). On the contrary, if the flows accelerate on steep slopes and incorporate ambient water they can transform into more diluted flows (Fig. 7).

The transformation of a hyperconcentrated flow into a concentrated flow and finally a sediment-laden turbulent flow has been described in detail by Mutti (1992) and Mutti et al. (2003), and requires a flow transformation and a hydraulic jump. As a consequence of these transformations an important volume of ambient water is incorporated in the flow, resulting in the washing-out of extrabasinal light components, which will be segregated towards the flow tail (Zavala et al. 2012). In consequence, the resulting deposits of these concentrated sediment-laden turbulent flows (facies F4-F9 from Mutti 1992) will probably lack extrabasinal components, making difficult its differentiation from intrabasinal turbidity current deposits.

\subsection{Concentrated flows and their resulting deposits}

Concentrated flows (CF) are turbulent, inertia-dominated flows (Beverage and Culbertson 1964; Pierson and Scott 1985; Costa 1986; Smith 1986; Pierson and Costa 1987; Weirich 1989; Smith and Lowe 1991; Mutti 1992; Mutti et al. 1999; Mulder and Alexander 2001) where grain-tograin interaction is the main grain support mechanism (Bagnold 1954, 1962). Concentrated flows are equivalent to high-density turbidity currents (HDTC, Lowe 1982; Mutti 1992).

According to Mulder and Alexander (2001), concentrated flows have a density ranging from $9 \%$ to $40 \%$ in volume of sediments (Fig. 3). Figure 9 depicts the situation when a subaerial concentrated flow enters in a marine or lacustrine basin and transforms into a hyperpycnal concentrated flow. According to the associated basin morphology, two different situations are possible: 1) primary accumulation from the original parent flow and 2) transformation of a concentrated flow into a sediment-laden turbulent flow, through the incorporation of ambient water and a hydraulic jump. Deposition from the original parent flow occurs by frictional freezing. Typical deposits of hyperpycnal concentrated flows are composed of massive (often showing dish structures) medium- to coarse-grained sandstones (facies F5 of Mutti 1992) with extrabasinal components like charcoal clasts (Fig. 10a, b, and e). If the velocity decrease is more gradual, concentrated flows can segregate a slow moving basal sub-layer allowing the generation of traction carpets (Lowe 1982). Traction carpet deposits compose cm-thick inverse-graded layers (facies F4 of Mutti 1992) often located at the base of coarse-grained massive sandstones (Fig. 10c).

The effectiveness of grain-to-grain interaction as a sediment support mechanism is highly dependent on grain size and flow velocity (to enhance the effect of dispersive pressure), and therefore requires steep slopes

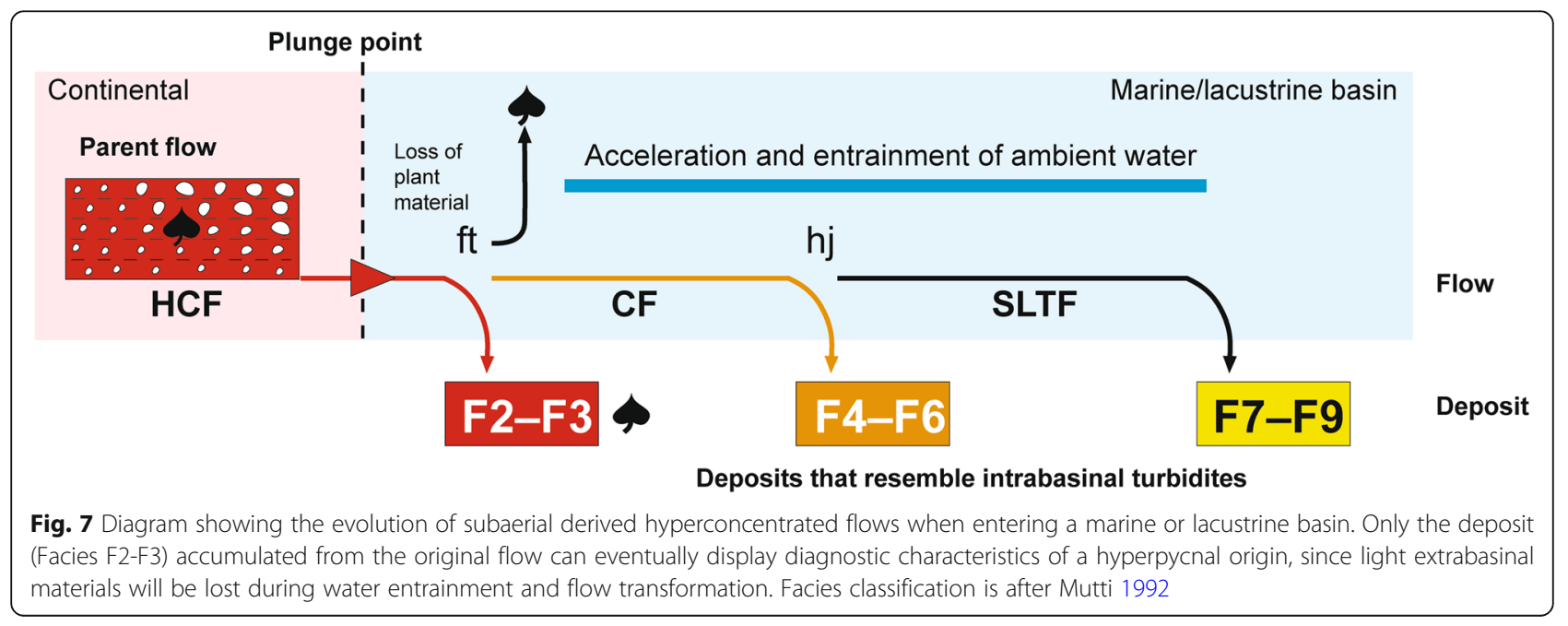



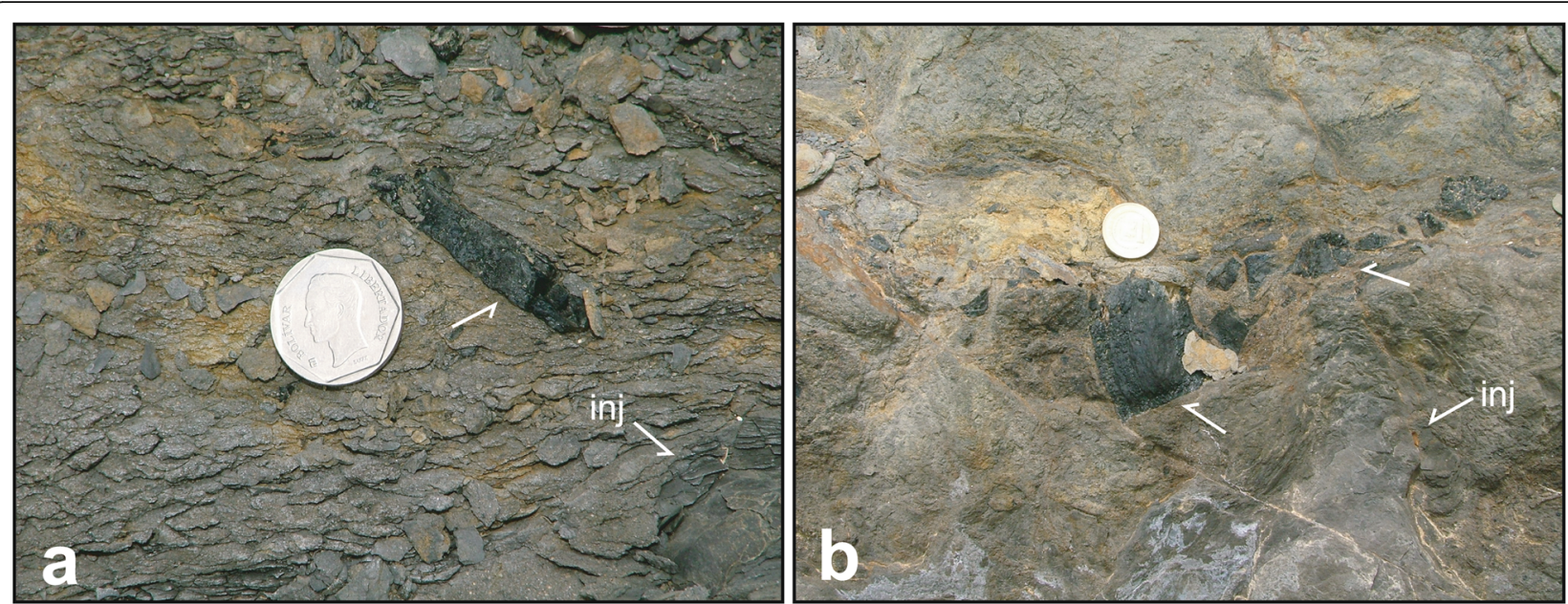

Fig. 8 Example of deposits related to extrabasinal hyperconcentrated flows (facies F2 of Mutti 1992). a, b Mud-rich, poorly sorted sandstones with large coal clasts (arrows). Note that in general these deposits are better sorted than those related to cohesive debris flows due to the lower matrix cohesion in HCF, which limited the support of large clasts. The accumulation over a poorly consolidated substrate results in shale injection (inj). Deep-water deposits from the Eocene Guarico Formation, Venezuela. Coin diameter in both photographs is $25 \mathrm{~mm}$

(Mulder and Alexander 2001). During its travel basinward, a concentrated flow rapidly evolves into a bipartite flow (Sanders 1965; Mutti et al. 1999) characterized by a frontal fast-moving inertia flow followed by a slowmoving sediment-laden turbulent flow. Grain-to-grain interaction is a poorly efficient sediment support mechanism since it dissipates a lot of energy. In consequence if the slope progressively decreases, the flow will be forced to stop due to the increasing friction. For this reason, deposits of concentrated flows are usually located at base of slope areas (Mutti 1992). When the fast-moving inertia flow stops, the slower moving segregated suspension cloud bypasses the coarse-grained concentrated flow deposits sometime producing some reworking in the form of lens-shaped sand bodies often showing cross-bedding (facies F6 of Mutti 1992, see
Fig. $10 \mathrm{f}$ and Fig. 11). Figure 10d provided an exceptional example of concentrated inertia flow deposits sharply overlain by sediment-laden turbulent flow deposits with large coal clasts. It is interpreted that these coal clasts were segregated from the main inertia flow towards the slower moving low density suspension cloud.

The transformation of an inertia-dominated granular flow into a gravity-dominated turbulent flow occurs through a hydraulic jump. The final product after this transformation will be normally graded massive, laminated to rippled fine-grained sandstones, with an internal organization that closely resemble the conventional Bouma sequence (Bouma 1962). In consequence, the differentiation of these extrabasinal turbidites from those generated by intrabasinal flows could be very difficult.

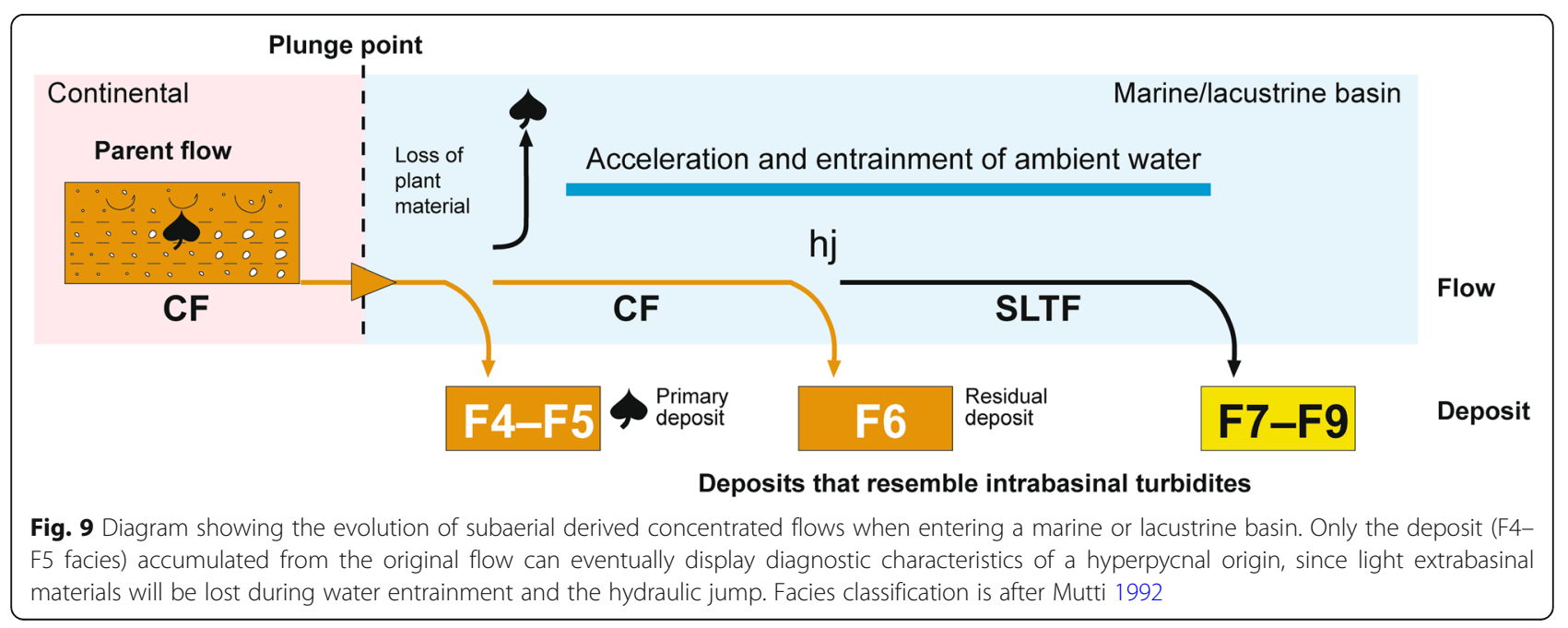



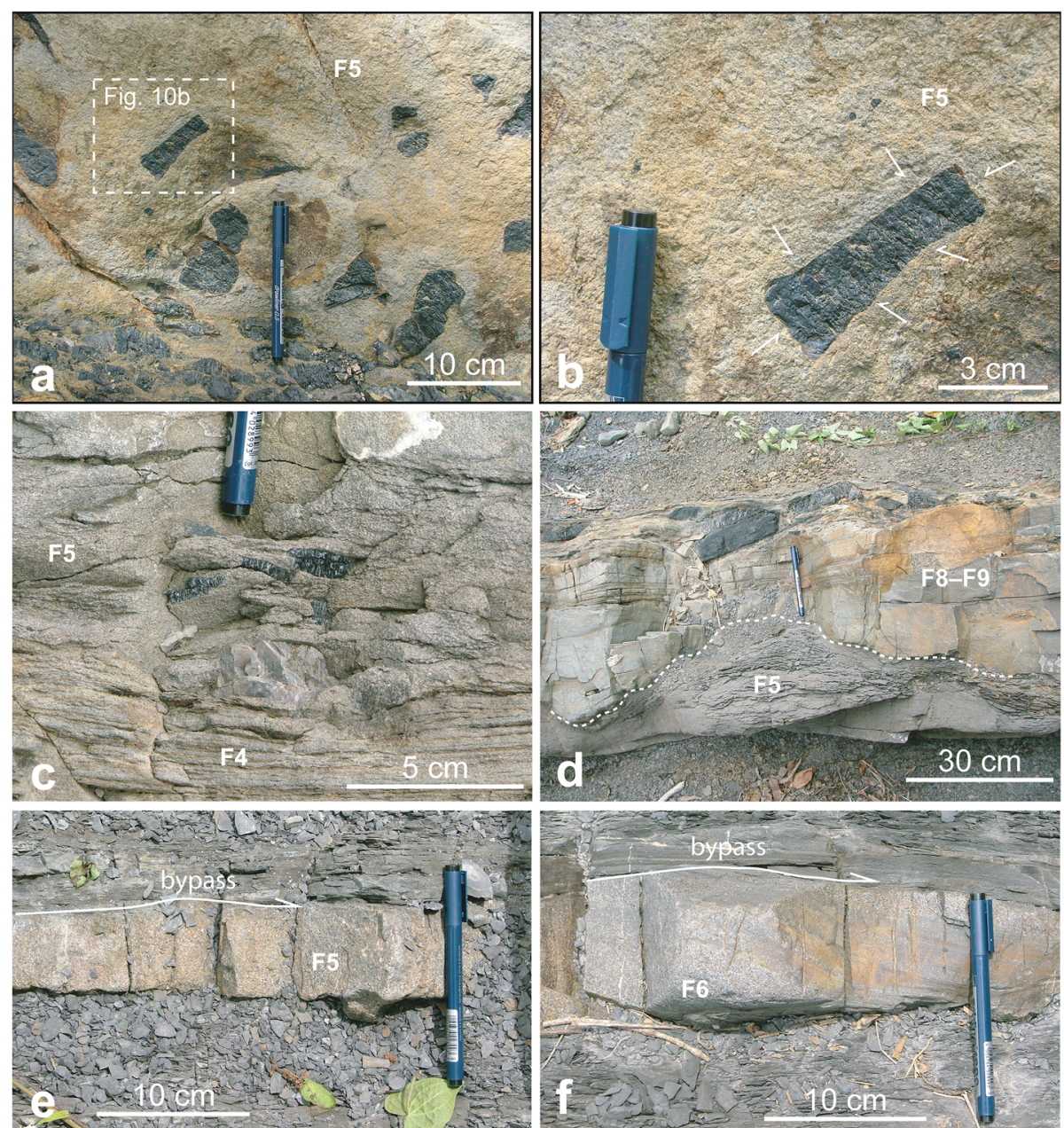

Fig. 10 Examples of deposits related to extrabasinal concentrated flows. $\mathbf{a}, \mathbf{b}$ Detail (a) and close up (b) of coarse-grained, massive sandstones (F5) with abundant floating coal clasts. The concave outer boundary of coal clast (b) suggests that the coal was poorly consolidated and was early "smashed" by lithostatic pressure; c Coarse-grained sandstones with traction carpets (F4) followed by massive sandstones with "dishes" and coal clasts (F5); d Residual, massive, coarse-grained sandstones (F5) irregularly covered by sediment-laden turbulent flow deposits with segregated coal clasts; e Residual, massive, coarse-grained deposits (F5) preserved at the base of a bypass surface (arrow); $\mathbf{f}$ Cross-bedded, coarse-grained sandstones (F6) produced by the reworking of the bypassing SLTF (arrow), after a hydraulic jump. Deep-water deposits from the Eocene Guarico Formation (Venezuela) at Panapo river section. Facies codes are from Mutti 1992

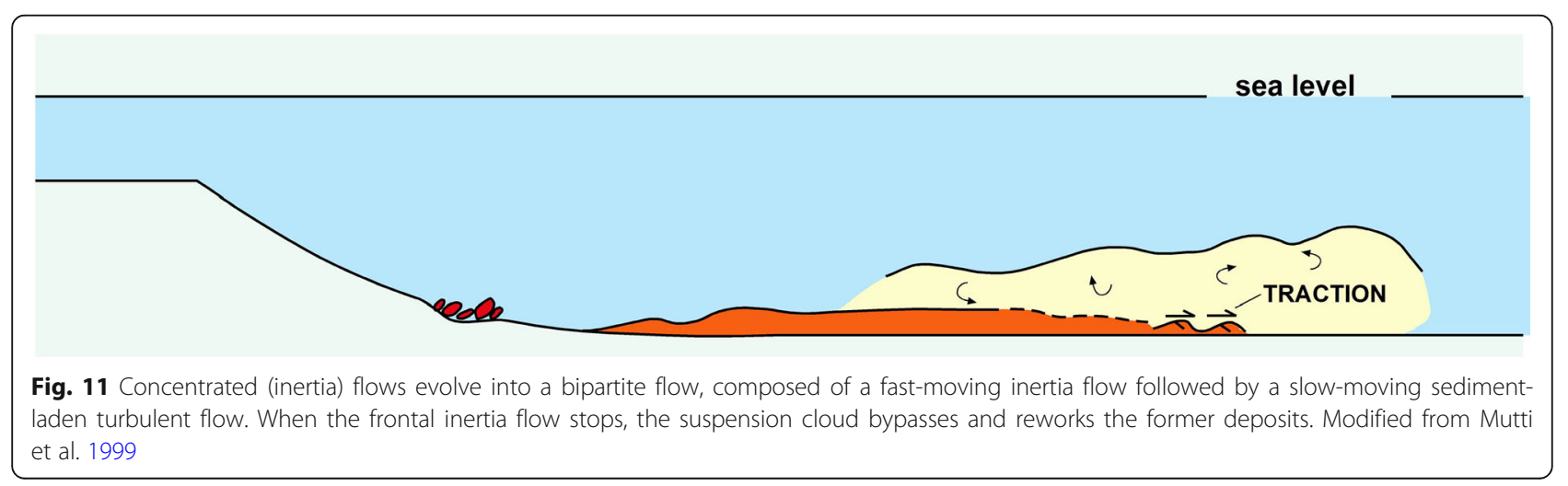




\subsection{Sustained, sediment-laden turbulent flows and their resulting deposits}

Sustained, sediment-laden turbulent flows (SLTF) are generated during exceptional river discharges. During river floods, the concentration of suspended sediments can substantially rise due to an increase in flow capacity, resulting in dirty rivers (Mulder et al. 2003). If these sediment-laden turbulent flows enter in a marine or lacustrine basin with enough sediment concentration (1 $\mathrm{kg} / \mathrm{m}^{3}$ in lakes and $35-45 \mathrm{~kg} / \mathrm{m}^{3}$ in sea water; Mulder and Syvitski 1995), they can go hyperpycnal. Sustained hyperpycnal flows are characterized by a slow-moving leading head with low entrainment of ambient waters (Zavala et al. 2006, 2011). Consequently, these extrabasinal flows can transfer a huge volume of freshwater and continental organics farther basinward. The last is very important for understanding the origin of organic shales, since it provides a new depositional mechanism for the accumulation of hot shales not related to the "normal" fallout of silt-clay materials in tranquil offshore waters.

The "unconventional" characteristics of sustained hyperpycnal flows also result in "unconventional" beds with distinctive characteristics that allow a clear differentiation respect to deposits related to intrabasinal (surge-like) turbidity currents. Some of these characteristics include (1) composite beds with gradual and recurrent changes in sediment grain-size and sedimentary structures (Zavala et al. 2007, 2011), (2) mixture of extrabasinal and intrabasinal components, (3) internal and discontinuous erosional surfaces, and (4) lofting rhythmites in marine/saline basins (Sparks et al. 1993; Zavala et al. 2012; Zavala and Arcuri 2016).

Depending on the grain-size of suspended sediments and the occurrence or not of associated bedload, riverfed sustained sediment-laden turbulent flows can result into pebbly, sandy or muddy hyperpycnal flows (Fig. 12).

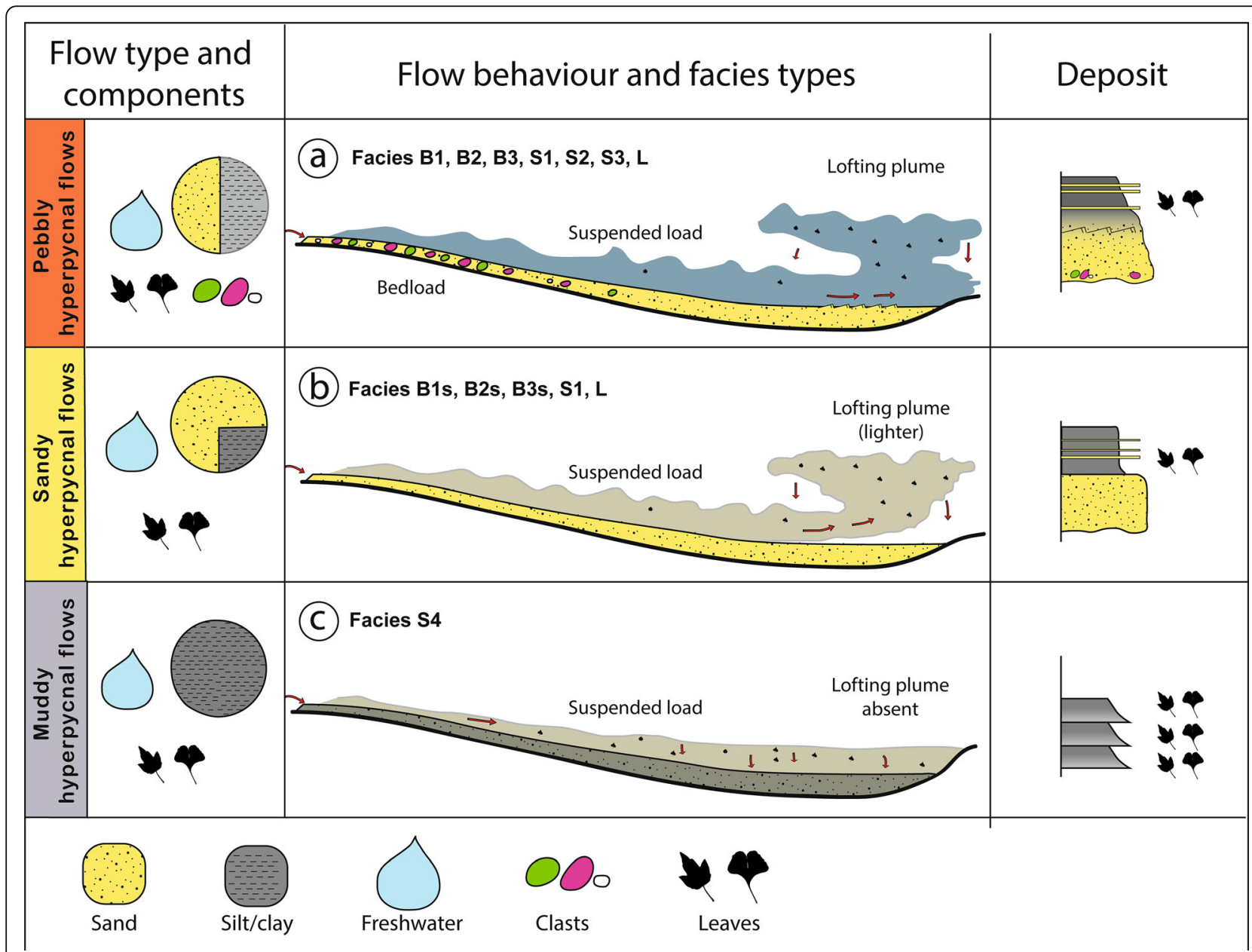

Fig. 12 Types of land-generated sediment-laden turbulent flows and resulting hyperpycnal flows and facies. a Pebbly SLTF, with extrabasinal-derived bedload common in proximal zones characterized by high shear forces; b Sandy SLTF. Bedload (if present) is composed of intrabasinal components like clay clasts; c Muddy SLTF. Due to the excess of density provided by the silt/clay suspension, the flow will be always attached to the basin bottom until the final deposition, and consequently lofting is not possible. See Fig. 14 for facies codes. Modified from Zavala and Arcuri 2016 


\subsubsection{Pebbly hyperpycnal flows}

Pebbly hyperpycnal flows are originated from subaerial, sustained sediment-laden turbulent flows with associated bedload (Fig. 12a). If the suspended sediment concentration in the flow is high enough to provide a relatively high bulk density (above the density threshold of lacustrine and marine waters; Mulder and Syvitski 1995), the river flow will plunge at coastal areas and generate a hyperpycnal flow (Fig. 13). Proximal facies include matrix-rich conglomerates (facies B), followed downstream by massive, laminated and rippled sandstones (facies $\mathrm{S}$ ). In marine settings freshwater can induce buoyancy reversal (lofting) when the flow loses part of the sandy suspended load by deposition, resulting in laminated siltstones with plant remains (facies L). Three types of bedload facies are recognized, termed B1, B2 and B3 (Fig. 14; Zavala et al. 2011). Facies B1 is composed of poorly organized clastor matrix-supported conglomerates with clast derived from extrabasinal sources (Fig. 14 a and Fig. 15 a, b and c). Matrix is commonly composed of well sorted fine- to medium-grained sandstones, accumulated when part of the suspended load is trapped at the lower flow boundary. Individual, large and elongated clasts commonly show imbrication, suggesting fluid flows where clasts could freely rotate at the base of a sustained flow that provides shear forces. Facies B2 is composed of clast- to matrix-supported conglomerates and pebbly sandstones with low angle asymptotic cross bedding (Fig. 14 a and Fig. 15 d). Field evidences suggest that this facies is commonly part of channel fill deposits, where the flow is relatively confined. The asymptotic foreset suggests an origin associated with dunes characterized by flow expansion (Zavala and Pan 2018), evidencing high rates of fallout on the lee side.

Facies B3 is integrated by fine- to medium-grained sandstones with diffuse lamination and levels of parallel aligned clasts (Fig. 14 a and Fig. 15 e). This facies is formed by poorly confined flows with pulsating energy, resulting in alternating fallout-bedload deposition.

Suspended load facies include massive (facies S1), laminated (facies S2) and rippled (facies S3) finegrained sandstones (Fig. 14a). All these facies are originated by the progressive loss of flow capacity of the sustained hyperpycnal flow (and related collapse of suspended materials) under different rates of sediment fallout and flow velocity (Zavala and Pan 2018). In shelfal areas, the accumulation of fine-grained sand from turbulent suspensions can be locally affected by flow anisotropy (combined flows) or waves, resulting in sandstone beds with hummocky cross-stratification (facies S2h) and wave ripples (facies S3w), Fig. 14a.

In marine or saline basins, the relative loss of weight associated with sand deposition can produce a flow buoyancy reversal due to the lifting effect of interstitial freshwater, generating suspension (lofting) plumes (Sparks et al. 1993). The gravitational collapse of these lofting plumes results in the accumulation of heterolithic intervals composed of poorly bioturbated rhythmic intercalations of graded silt levels with plant remains and micas, known as lofting rhythmites (Zavala et al. 2008, 2012).

Facies related to lofting processes are common at channel/lobe margins, and are composed of massive sandstones with some discontinuous silt levels (facies S1L), laminated sandstones with silt levels (facies S2L), alternating laminated siltstone levels with low angle ripples (facies S3L) and laminated fine-grained sandstone/

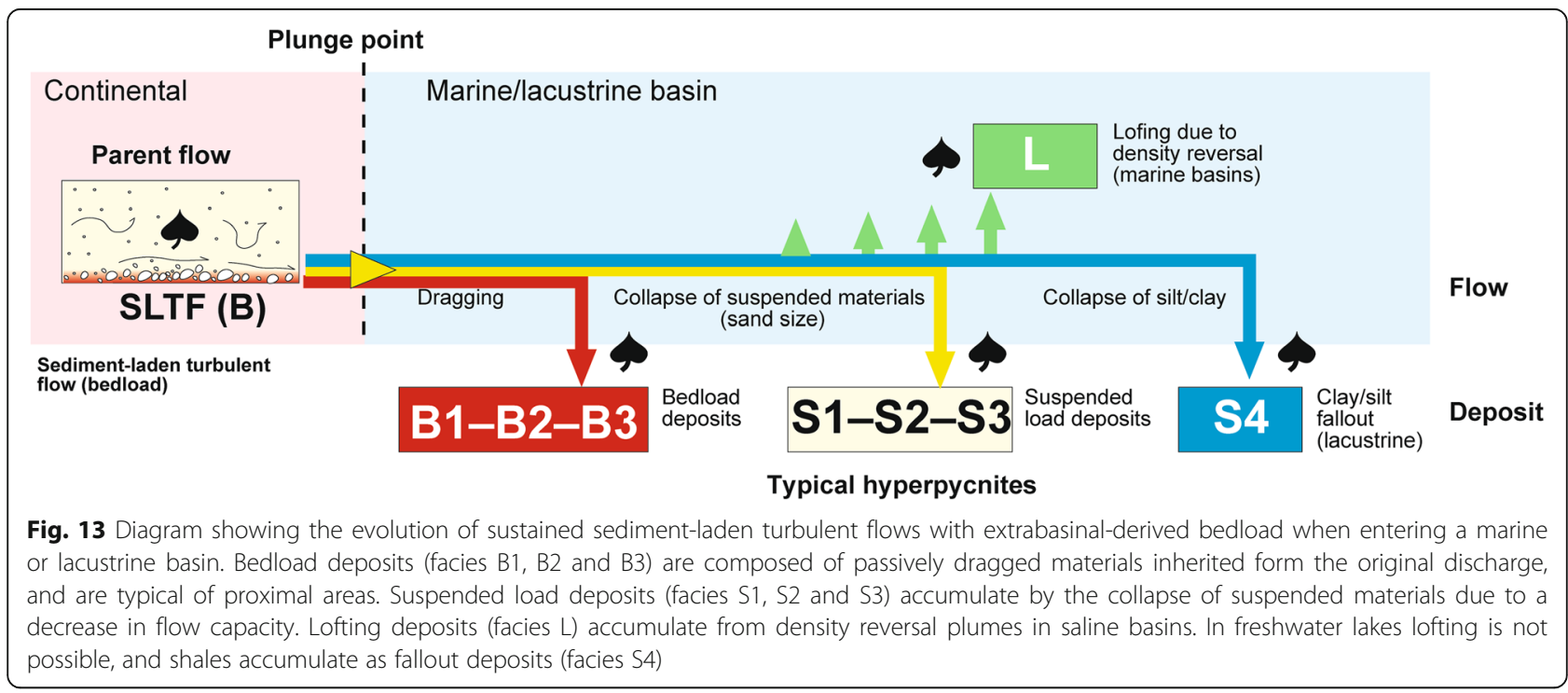




\section{A Longitudinal facies changes (100's km)}

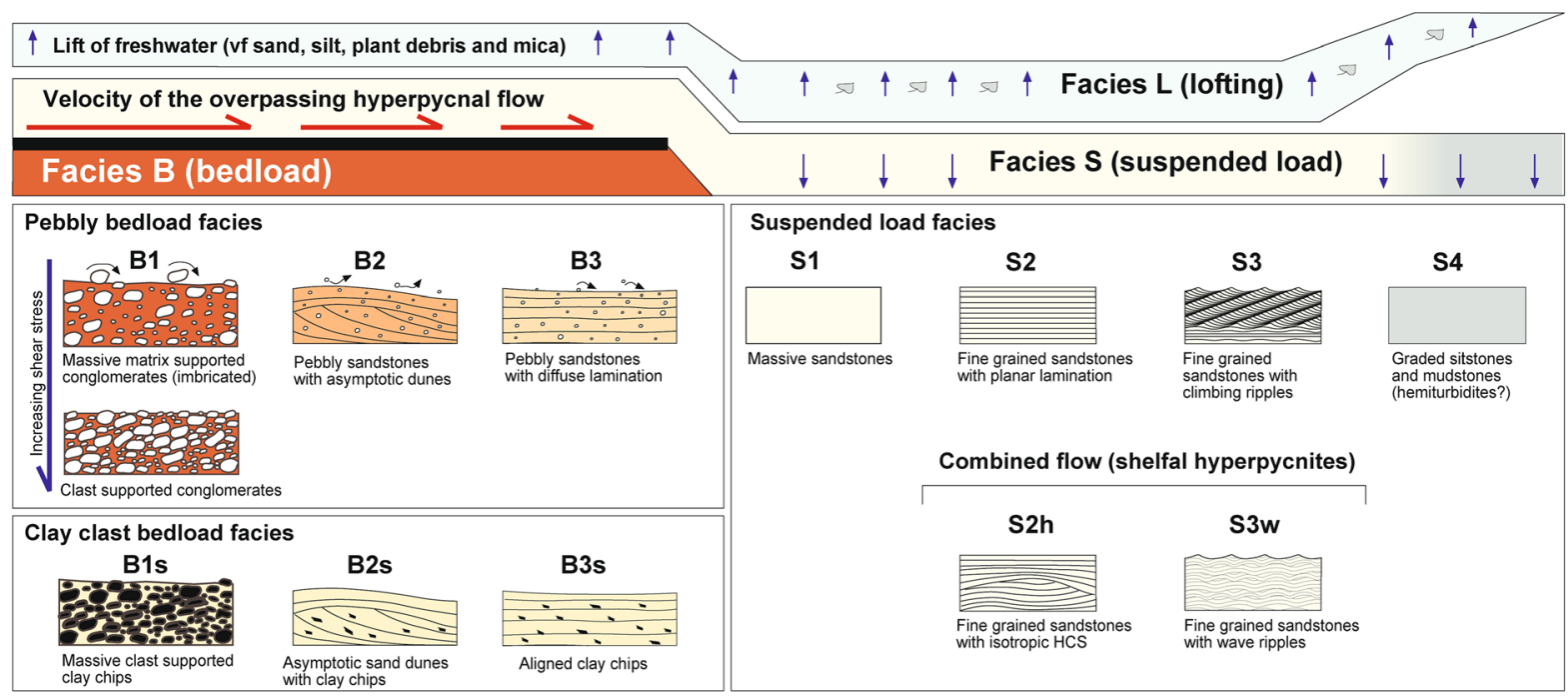

Channels

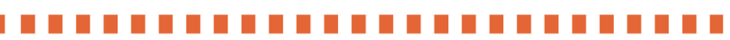

Lobes

\section{b Lateral facies changes (100's m)}
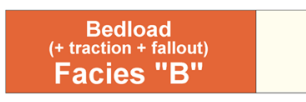

Traction + fallout
Facies "S"

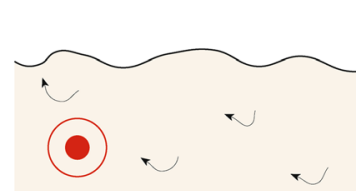

Channel axis

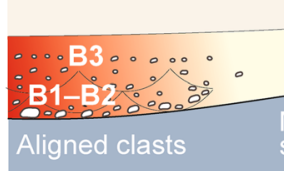

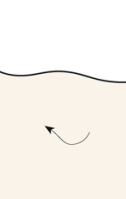
1 Massive Massive
sandstone

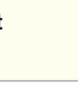

$\sqrt{2}$

$\sqrt{2}$

Lofting plume (fallout)
Facies "L"

Fig. 14 Genetic facies tract for the analysis of deposits accumulated by sustained hyperpycnal flows with associated bed load. a Facies association along the entire depositional system (commonly 100's of km); b Lateral facies changes towards flow margins (typical 100's of meters). Note that lofting facies are typical of flow margin areas in marine and saline lakes. Modified from Zavala and Pan 2018. LP = Lofting point siltstones (facies L), Fig. 14b. Plant remains and micas are very common in all lofting-related facies, often draping different laminas and depositional surfaces. The presence of lofting-related deposits is very important because it provides a non-biological criterion for the recognition of marine/saline basin waters. In freshwater lakes, since the density of the interstitial water within the hyperpycnal flow is similar to that of the reservoir, lofting is not possible.

Deposition from hyperpycnal flows with early density reversal in marine/saline basins can result in enigmatic, incomplete Bouma sequences (Fig. 15f), composed of massive, fine-grained sandstones (facies S1) sharply overlain by laminated siltstone levels with plant remains (facies L). This situation is possible when the hyperpycnal flow is detached from the depositional bottom (buoyancy effect) before achieving the velocity to form laminated or rippled sandstones. The critical flow velocity for lofting (lofting point) largely depends on the amount of clay in the turbulent suspension. As an example, if the hyperpycnal flow is clay-free, then the flow can start floating at a higher critical velocity because of the lifting effect of freshwater, resulting in top-missing Bouma sequences. On the other hand, a hyperpycnal flow having a higher clay content will be "denser", allowing the accumulation of laminated and rippled 


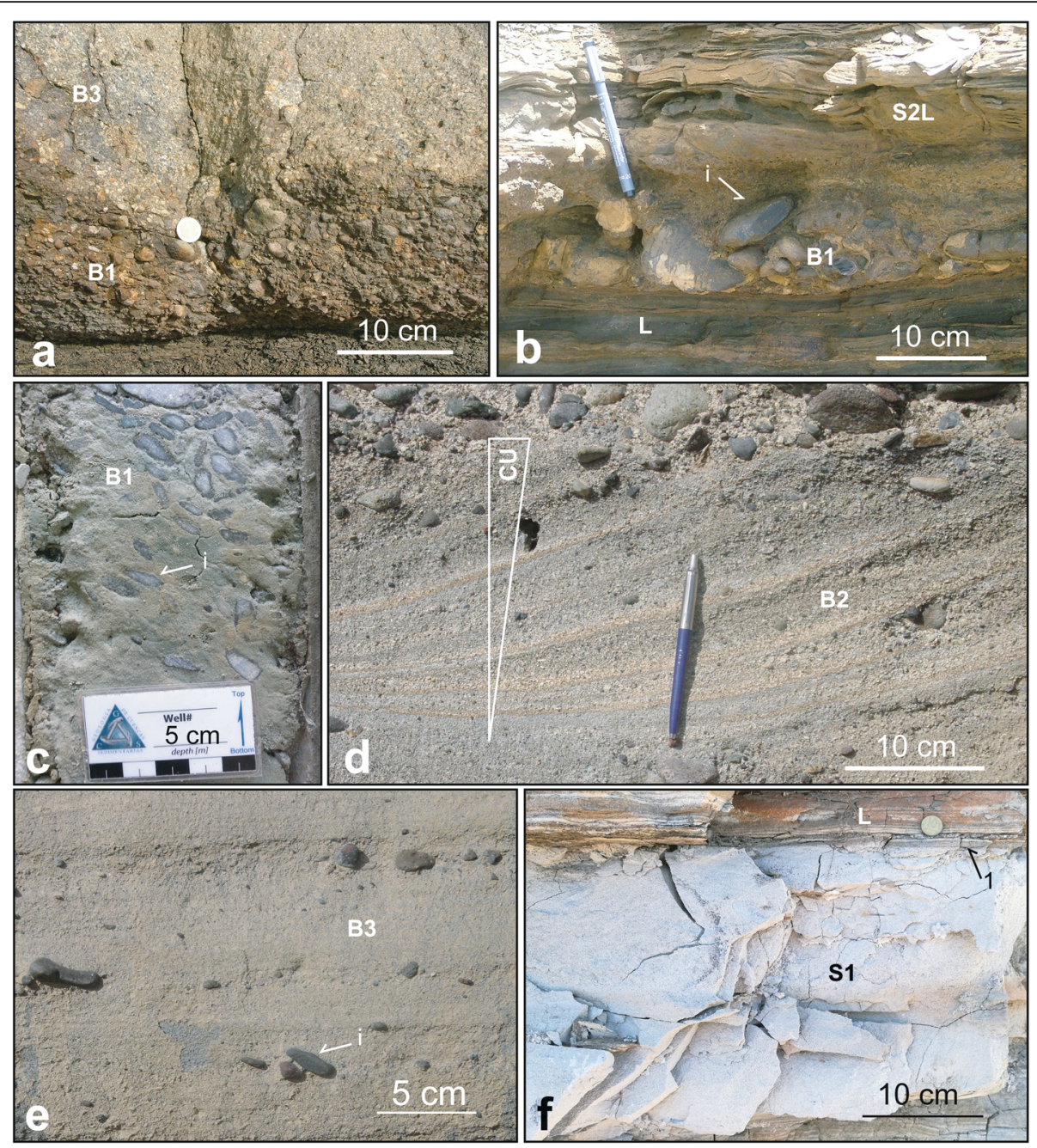

Fig. 15 Examples of facies related to pebbly hyperpycnal flows. a Facies B1 is composed of matrix-rich clast supported conglomerates with imbricated clasts. Middle Jurassic Los Molles Formation, Argentina; b Bedload "overspill" on proximal levee deposits. Note clast imbrication. Eocene Pampatar Formation, Margarita Island, Venezuela; c Matrix-rich, imbricated conglomerates (facies B1). Lower Cretaceous Centenario Formation, Argentina; $\mathbf{d}$ Asymptotic cross bedding with floating pebbles. Note the coarsening upward trend, which is typical of sediment-laden turbulent flow deposits; e Fine- to medium-grained sandstones with floating and imbricated pebbles. Examples $\mathbf{d}$ and $\mathbf{e}$ are from lacustrine deposits of the Pleistocene Huarenchenque Formation, Argentina; f Massive, fine-grained sandstones (facies S1) sharply overlain by heterolithes composing a Bouma top-missing sequence (1). The laminated interval on top is interpreted as lofting fallout deposits (facies L). Middle Jurassic Los Molles Formation, Argentina. i: Imbrication

sandstones also in marine settings. The absence of lofting in freshwater lakes results in the common occurrence of planar lamination and climbing ripples in fine-grained sandstones. In this setting, sustained and velocity fluctuating SLTF often accumulate monotonous successions of fine-grained sandstones showing a cyclical recurrence of climbing ripples, planar lamination and massive bedding. The final (distal) product of sustained hyperpycnal flows will be a deposit of graded shales corresponding to facies S4 (Fig. 14).

\subsubsection{Sandy hyperpycnal flows}

Sandy hyperpycnal flows are originated by the plunging of sustained, sediment-laden turbulent flows with a suspended load mainly composed of fine- to medium-grained sands (Fig. $12 \mathrm{~b}$ and Fig. 16). These sands are commonly previously matured and temporarily stored in coeval continental depositional environments, from where they are periodically removed and transferred into the basin by rivers during major floods. In the Early Cretaceous of the Neuquén Basin, SEM morphometric studies of grain surfaces revealed that fine-grained sands accumulated in 


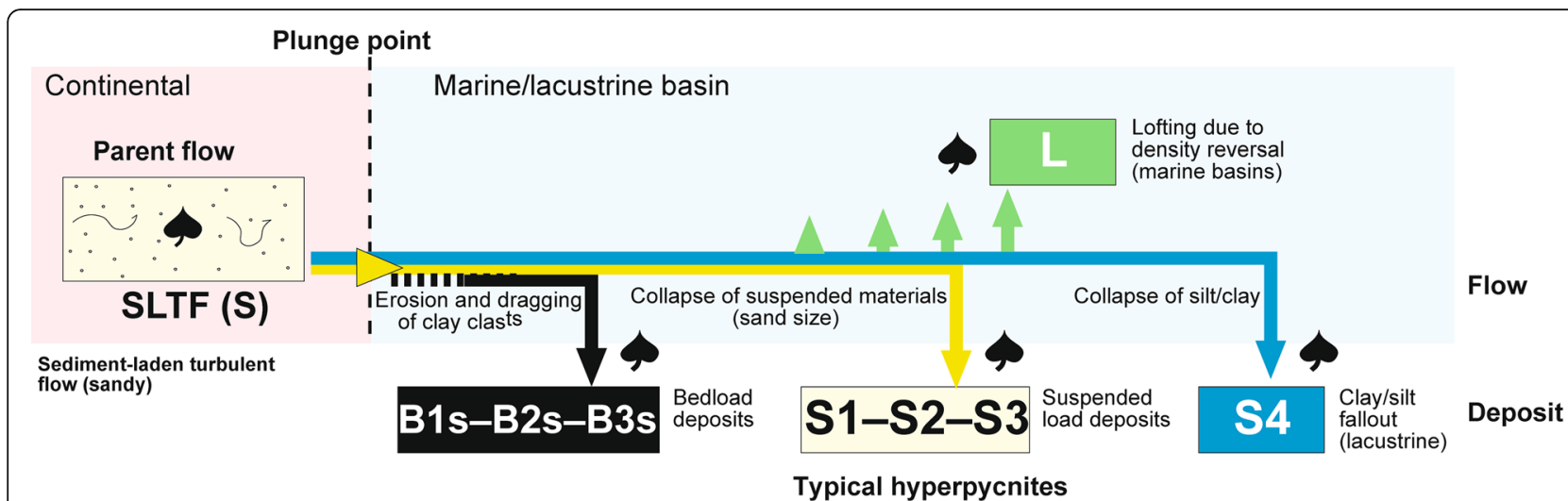

Fig. 16 Diagram showing the evolution of sustained, sandy sediment-laden turbulent flows when entering a marine or lacustrine basin. Bedload deposits (facies B1S, B2s and B3s) are composed of intrabasinal clasts (mostly shale clasts) floating in a sandy matrix, and are derived from the erosion of the basin substrate. Suspended load deposits (facies S1, S2 and S3) accumulate by the collapse of suspended materials due to a decrease in flow capacity. Lofting deposits (facies L) accumulate from density reversal plumes in saline basins. In freshwater lakes lofting is not possible, and shales accumulate as fallout deposits (facies S4)

the lacustrine Rayoso Formation derived from the erosion of a mature peripheral aeolian system (Zavala et al. 2006). Same situation has been proposed by Antobreh and Krastel (2006) for the erosion and deep-water transfer of aeolian sands, previously matured in a paleo-desert, into the Timiris Canyon in Mauritania. During the basinward transfer of these sands, hyperpycnal flows can erode the substrate, carve shallow channels and incorporate intrabasinal clasts (mostly soft clasts). Mud clasts are common in proximal areas, where they are dragged as bedload at the base of sustained turbulent flows. Resulting deposits compose matrix-rich conglomerates (facies B1s, Fig. 17a), low angle asymptotic cross bedding with floating clay clasts (facies B2s, Fig. 17b) and fine- to medium-grained sandstones with diffuse lamination and aligned and imbricated clasts (facies B3s, Fig. 17c, d, e and f), Fig. 14a.

The loss of channel confinement at the channel-lobe transition results in a drastic decrease of shear forces, and consequently bedload transport is significantly reduced as the flow loses competence. When the main flow starts to wane, suspended-load materials are progressively segregated at the lower flow boundary. This deposition is a consequence of a loss in flow capacity, with the resulting accumulation of massive (facies S1, Fig. 18a, b and e), laminated (facies S2, Fig. 18f) and rippled (facies S3, Fig. 18 f) sandstones. Massive sandstones are largely the most common deposits of hyperpycnal flows. Most pebbly- and sandy-hyperpycnal deposits show more than $70 \%$ of massive sandstones. A diagnostic criterion that allows the differentiation of massive sandstones originated from intrabasinal or extrabasinal flows is the existence of plant remains in between sand grains (leaves, trunks, charcoal etc., Fig. 18e). Plant remains included within sand grains constitute a direct evidence that suggests that these extrabasinal components were present in the parent flow and were trapped during the collapse of the main suspended sandy load (Zavala et al. 2012). Experimental studies demonstrate that fine-grained massive sandstones accumulated from the gradual collapse (aggradation rates $>0.44 \mathrm{~mm} /$ s) of fine-grained sand/silt suspended load from a sustained sediment-laden turbulent flow (Banerjee 1977; Arnott and Hand 1989; Sumner et al. 2008). If this turbulent flow is trapped in a confined topographic area, massive sandstones can aggrade forming very thick sandstone bodies. Figure 18a provide an excellent example of confined lobes from the Middle Jurassic Lotena Formation, in the Neuquén Basin. When observed in detail, these fast aggrading massive sandstones show a characteristic "banding" (Fig. 18b) produced during the progressive rise of the depositional surface by subtle cyclic changes in the fallout rate. In marine and saline lake basins, sandy hyperpycnal flows can also revert the flow density due to the buoyant effect of freshwater, especially towards flow margins. As in pebbly hyperpycnal flows, the effect of flow lofting can result in the accumulation of top missing Bouma's sequences (Fig. 18c and e), where massive fine-grained sandstones (facies S1) are overlain by laminated sand-silt couplets (facies L).

\subsubsection{Muddy hyperpycnal flows and their resulting deposits}

Muddy hyperpycnal flows are originated by the plunging of sustained sediment-laden turbulent flows with a suspended load mainly composed of a clay-silt fraction. Growing evidences (Bhattacharya and McEachern 2009; Abouelresh and Slatt 2011; Mulder and Chapron 2011; Wilson and Schieber 2014; Lash 2016) suggest that these land-generated fluid mud flows are very common in the stratigraphic record, and provide a rational mechanism to justify the accumulation of very thick successions of 


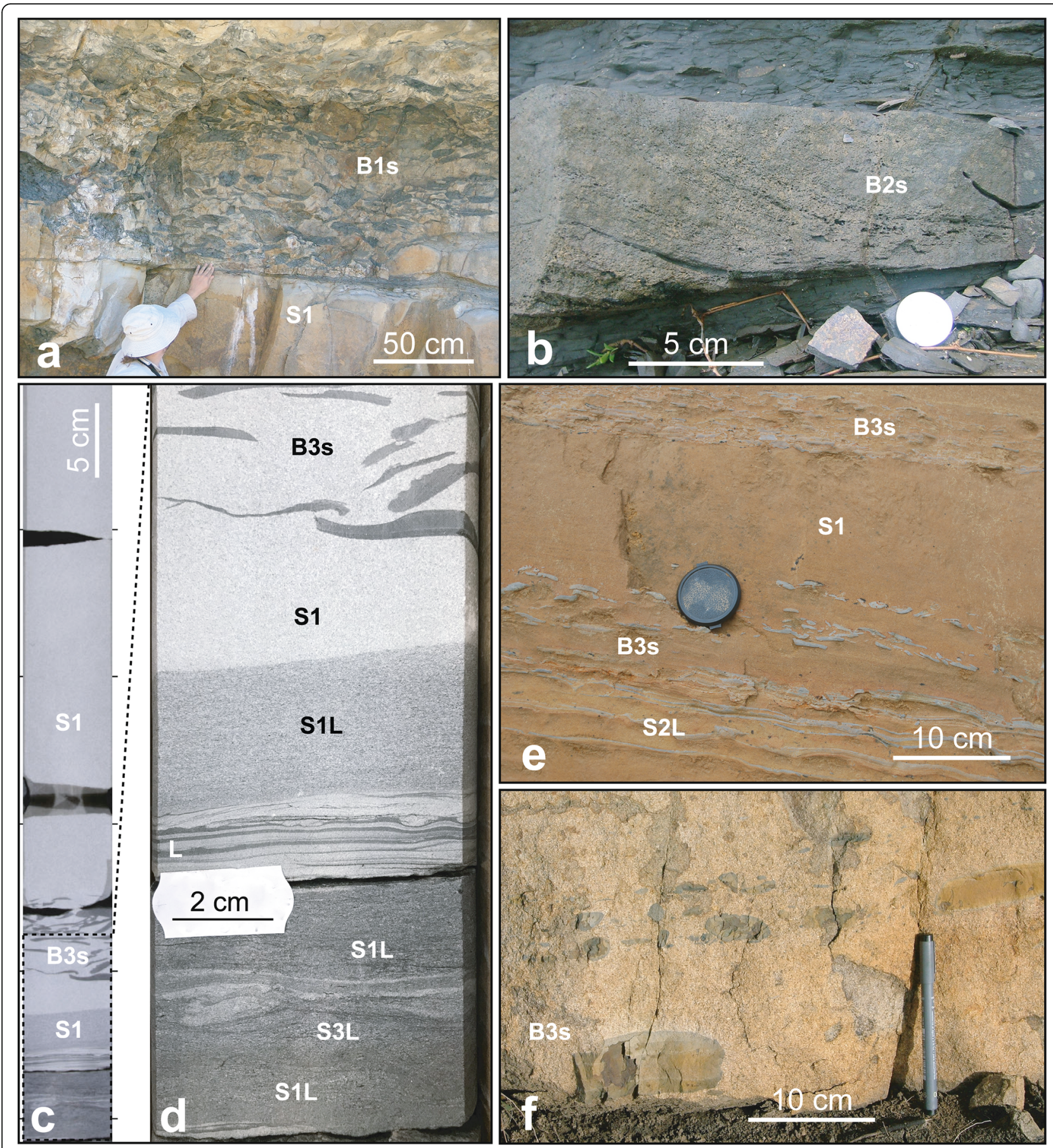

Fig. 17 Bedload facies related to sandy hyperpycnal flows. a Clast- to matrix-supported conglomerates, with large clay clasts (facies B1s); b Low angle asymptotic cross bedding with abundant clay clasts (facies B2s); c, d General view (c) and close up (d) of sandy hyperpycnal flow deposits. Note that massive sandstones with clay clasts (facies B3s) transitionally overlie massive sandstones (facies S1) and levee deposits (facies S1L and L), suggesting a gradual flow expansion. Deep-water marine deposits, Lower Cretaceous Achimov Formation, West Siberia, Russia; e Massive sandstones with aligned clay clasts (facies B3s). Pliocene deep-water deposits from Mayaro Formation, Trinidad; $\mathbf{f}$ Medium-grained sandstones with aligned clay clasts (facies B3). a, b, f Offshore deposits from the Lower Jurassic Los Molles Formation, Neuquen Basin, Argentina

shale, previously interpreted as deposited by normal "pure" fallout (e.g. Pettijohn 1975). If these muddy flows are sustained for long periods they can travel 100's of $\mathrm{km}$ along the sea bottom (Nakajima 2006; Soyinka and
Slatt 2008; Wilson and Schieber 2014, 2015), transferring huge amounts of mud and particulate organic matter to the inner basin (Biscara et al. 2011; Baudin et al. 2017a, 2017b; Mignard et al. 2017). Contrary to sand-size 


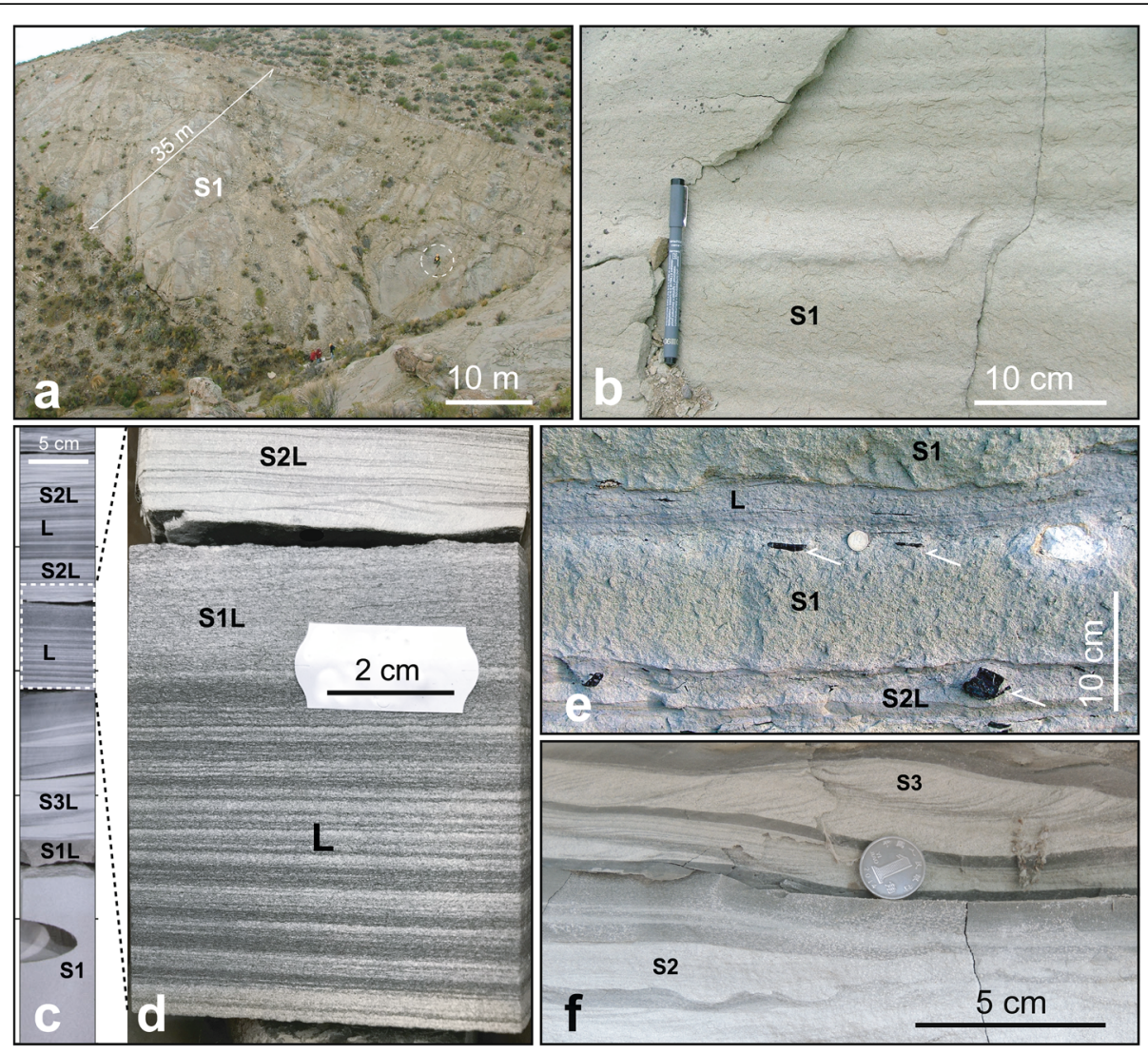

Fig. 18 Suspended load and lofting facies associated to sandy hyperpycnal flows. a Very thick sandstone bed ( $35 \mathrm{~m}$ thick) accumulated in topographic confined areas. A encircled person for scale; $\mathbf{b}$ Detail of sandstones in $\mathbf{a}$. Note the sub-horizontal, diffuse lamination generated by fluctuations in the rate of sediment fallout. Middle Jurassic Lotena Formation, Neuquén Basin, Argentina; c, d General view (c) and detail (d) of lobe to lobe-margin transition deposits. Note in $\mathbf{c}$ the top missing Bouma sequence (massive sandstones), and in $\mathbf{d}$ the highly continuous laminas with abundant plant debris, accumulated by fallout from lofting plumes ( $L$ facies). Deep water marine deposits, Lower Cretaceous Achimov Formation, West Siberia, Russia; e Massive sandstones with charcoal clasts transitionally covered by lofting deposits. Deep-water Miocene deposits from the Austral Basin, Argentina; f Laminated (facies S2) and climbing rippled (facies S3) sandstones. Lacustrine deposits from the Triassic Yanchang Formation, Ordos Basin, China

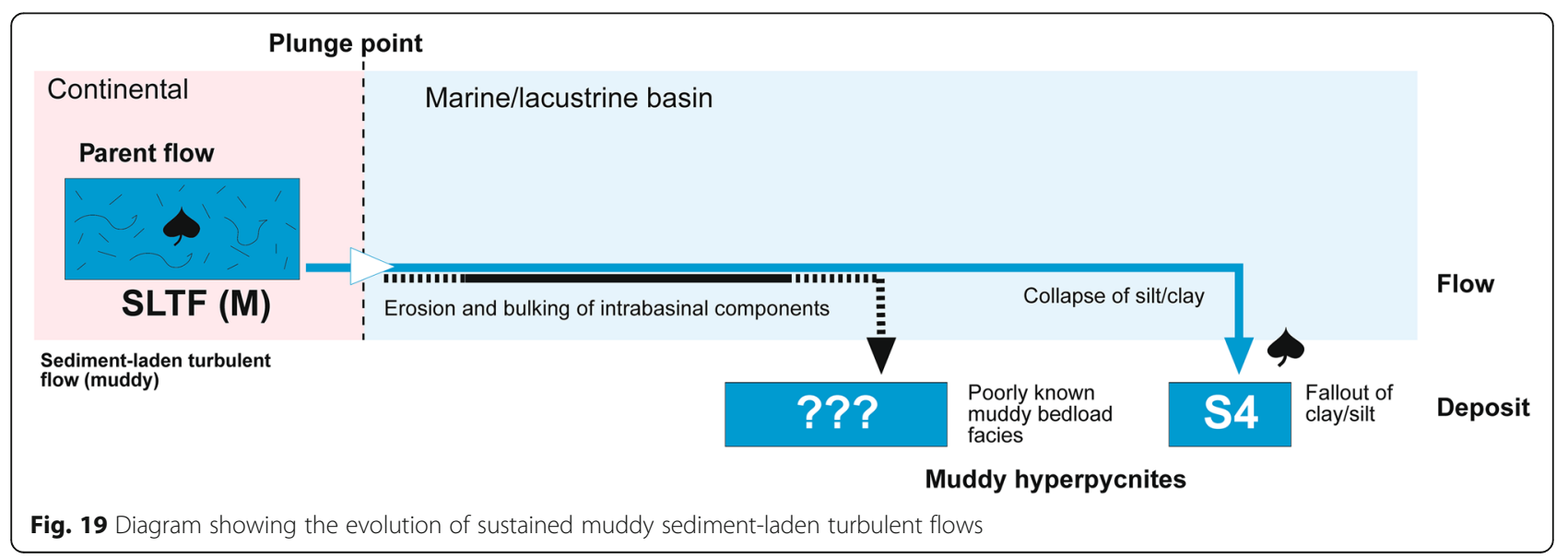


materials, the concentration of these fine-grained fractions in a turbulent suspension is not directly related to flow velocity. Consequently, in marine/saline waters, a waning muddy hyperpycnal flow will remain attached to the bottom until the flow completely stops without reverting its density (Fig. 19) and no lofting plumes will be generated (Zavala and Arcuri 2016). The analysis of fossil examples of muddy hyperpycnal flow deposits in cores and outcrops evidences a very complex hydrodynamics for these flows (Soyinka and Slatt 2008; Otharán et al. 2020). In outcrops, the study of mud flow deposits is facilitated by making macroscopic polished slabs of early diagenetic carbonate concretions. Early diagenetic concretions are very important because they can preserve a "frozen" record of the original depositional muddy fabric (Otharán et al. 2018, 2020), often highly deformed by compaction (Schieber et al. 2010).
A common characteristic of these muddy deposits is the existence of an impressive erosional basal boundary, which suggests basin bottom erosion by passing-by flows, with the associated incorporation of intrabasinal materials like microfossils and organic matter (Fig. 19). Consequently, the resulting deposits are often characterized by a complex mixture of intrabasinal and extrabasinal components (Zavala and Arcuri 2016; Otharán et al. 2018). The join occurrence of different paleodepth indicators in single beds is very common, and could be wrongly interpreted as indicative of a "transitional" environment with drastic changes in sea level. As a norm in these deposits, the deepest indicator is always the most reliable for paleodepth analysis. In proximal transfer areas, above the basal erosional surface, muddy hyperpycnal flow deposits commonly show poorly known bedload (?) sedimentary structures (Fig. 19) characterized by complex,

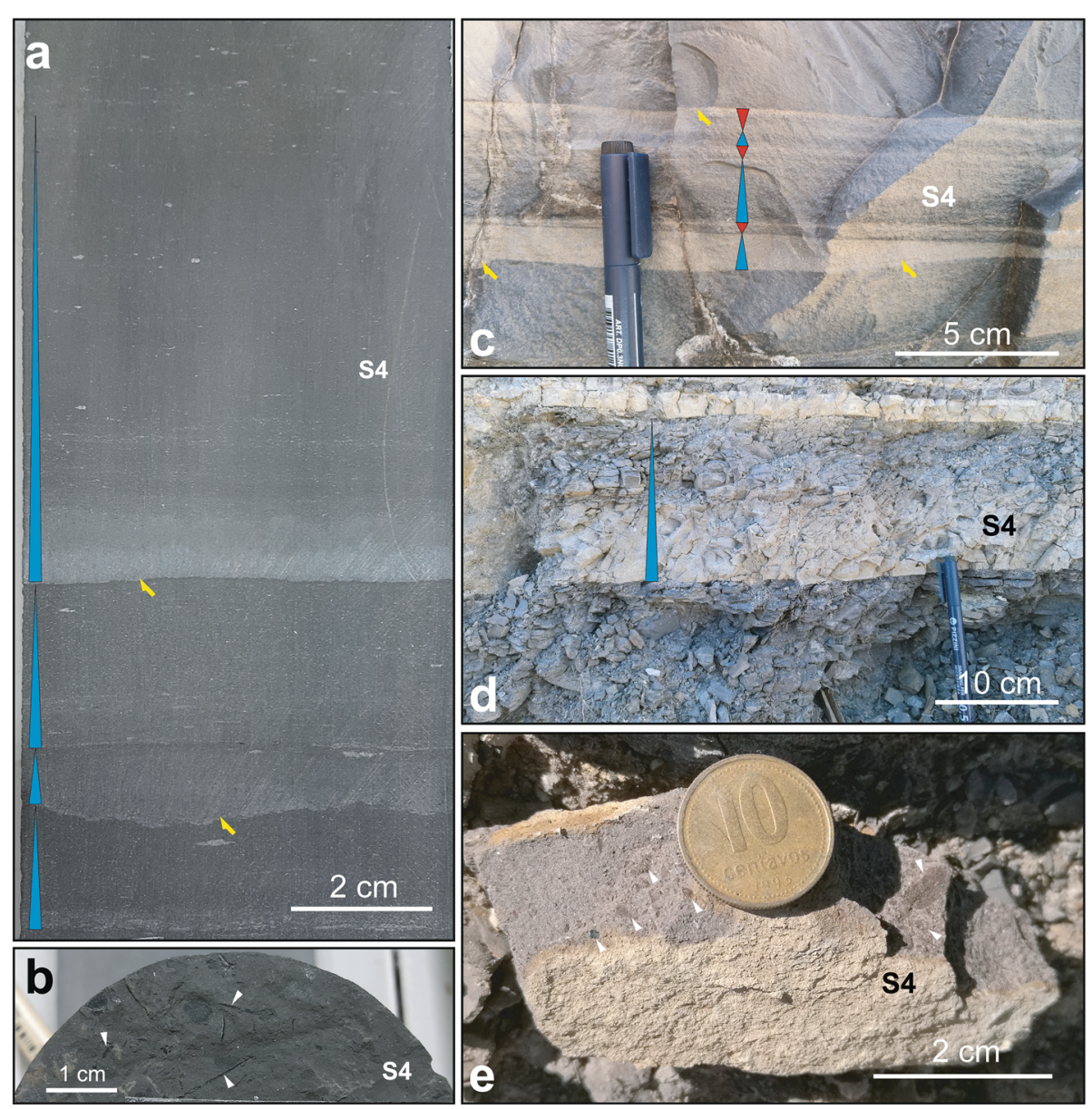

Fig. 20 Examples of muddy hyperpycnal flow deposits (facies S4). a Core example showing graded muddy intervals, resting on erosional bases (yellow arrows); b Detail of the core surface, showing abundant dispersed plant remains (white arrows); c Complex graded bed preserved in a cemented concretion. Note the multiple fining and coarsening upward cycles, accumulated over a basal erosional surface (yellow arrows). a-c Offshore Upper Jurassic deposits from the Vaca Muerta Formation, Neuquén basin, Argentina; d Normally graded silt levels, suggesting an accumulation from a fluid mud flow; Offshore Lower Jurassic deposits of the Los Molles Formation, Neuquen Basin, Argentina. e Detail of $\mathbf{d}$, showing a high content of dispersed plant remains (white arrows) 
coarsening- to fining-upward, cm-thick silty intervals (Fig. 20a, c). Once achieving the lower basin landscape these fluid mud flows stop, forming a concentrated clayrich basal layer from where normal settling and flocs accumulate normally graded silt-clay tabular deposits with abundant dispersed plant debris (Fig. 20b, d, e).

At seismic scale, the origin of very thick shale intervals can be inferred by the overall geometry of the deposit. When accumulating over an irregular landscape, fluid mud flow deposits show a lenticular shape often passively infilling lower topographic areas. In contrary, shale deposits accumulated by fallout are characterized by a regular thickness that passively "drapes" the underlying irregular topography.

\section{Discussion}

Rock weathering is the main source of unconsolidated clastic sediments on land (Sawyer 1986). In order to maintain the equilibrium, these sediments must be periodically (cyclically) removed, transferred and stored in subsiding areas (sedimentary basins), which are mostly subaqueous (Schumm 1977). Water streams play a very important role in subaerial landscapes allowing the longdistance sediment transfer, since they substantially contribute in reducing friction. In consequence, cycles of sediment production, transferring and deposition will be mainly controlled by climatic changes, since climate controls the amount of water periodically supplied to the system. The understanding of these simple concepts enhanced the importance of climate, fluvial systems, and hyperpycnal systems in providing a comprehensive explanation for the origin of the thickest and cyclically stacked (in different orders) sedimentary successions commonly found on shallow to deep water successions. This simple transfer-depositional model contrasts with the complexity and variety of depositional environments described in sedimentology textbooks.

Following Hutton's concept "present is the key to the past" almost all continental/littoral geomorphological environments were recognized and classified during the nineteenth century. Although most of these sedimentary environments are commonly located in long term erosion or low subsiding areas with limited chances of preservation (e.g. fluvial valleys), these geomorphologic environments have flooded our textbooks providing depositional models for the interpretation of almost all fossil successions. The fact is that continental/littoral environments represent only a small portion of the Earth surface. About $71 \%$ of our planet is covered by ocean waters, including a large number of still poorly known depositional environments. It seems that out key to interpret the past could be no good enough, and possible will require more studies focused on the understanding of present depositional environments.
During the twentieth century, the discovery of turbidites (Migliorini 1944; Kuenen and Migliorini 1950) and contourites (Heezen and Hollister 1964; Hollister 1967), constituted genuine advances for the modern sedimentology. More recently, the recognition of hyperpycnal flows and hyperpycnites provides a new perspective for the understanding of very thick ancient successions, which origin is often difficult to be explained according to conventional paradigms.

Hyperpycnal flows are subaqueous gravity flows defined by their extrabasinal origin. Consequently, it is not possible to define a hyperpycnal flow according to its composition, density, rheology or sediment support mechanisms, since it can be originated from a wide range of subaerially derived sediment gravity flows. Although land generated cohesive debris flows, hyperconcentrated flows, and concentrated flows can generate surge-like hyperpycnal flows, the volume of sediments accumulated by these flows is small compared to that related to sustained sediment-laden turbulent flows.

At present, our understanding of hyperpycnal flows and deposits is still poor and further studies are required. Of particular interest is the understanding of muddy hyperpycnal flows, since it provides a very exciting alternative explanation for the origin of organic rich shales.

\section{Conclusions}

1) Hyperpycnal flows can be generated by different types of subaerially derived sediment gravity flows when enter in marine or lacustrine basins. The only prerequisite is to supply a land-generated flow having a higher bulk density respect to that of the receiving water body. This situation is also possible for pyroclastic flows, although hyperpycnal pyroclastic flows are poorly known compared to conventional hyperpycnal gravity flows.

2) Cohesive debris flows, hyperconcentrated flows and concentrated (granular) flows are typical of high gradient settings (mountainous areas), and related to highly discontinuous (episodic) events. Once entering the basin, these high-density hyperpycnal flows can accumulate primary deposits or can transform into more diluted flows. The last transformation requires acceleration and entrainment of ambient water, conditions that are only possible along high-gradient basin slopes. The final deposit commonly lacks extrabasinal light materials like plant remains, wood and charcoal, and can consequently be easily confused with deposits of intrabasinal turbidites.

3) Sediment-laden turbulent flows at river mouths can be episodic or long lived (sustained). Once plunged, episodic sediment-laden turbulent flows usually do not form important hyperpycnal flow deposits, since these flows are short-lived and their related hyperpycnal deposits are accumulated at the lower delta front of littoral deltas. On the contrary, sustained sediment-laden 
turbulent flows can travel long distances (sometimes 100 's of $\mathrm{km}$ ) along the basin floor also across near flat basin areas. Since the entrainment of ambient water is very low, these flows can transport extrabasinal light materials (typical plant debris), freshwater and chemicals far from the coast line.

4) Depending on their composition, sustained sedimentladen turbulent flows can generate pebbly, sandy or muddy hyperpycnal flows. These long-lived flows are the most efficient mechanism for transferring an enormous volume of clastic sediments into marine and lacustrine basins. At present our understanding of these flows and their deposits is limited and more studies will be required in the future to achieve a better understanding.

\section{Abbreviations}

Fr: Froude Number; rt:: Rheological transformation; ft:: Flow transformation; hj: Hydraulic jump; i: Imbrication; CDF: Cohesive debris flows; HCF: Hyperconcentrated flows; CF: Concentrated flows; SLTF: Sediment-laden turbulent flows; HDTC: High-density turbidity currents

\section{Acknowledgements}

The author deeply acknowledges M. Arcuri, M Delgado, Livan Blanco Valiente and G. Otharán for their support and interesting discussions about hyperpycnal flow deposits. The comments and suggestions performed by two anonymous reviewers deeply contributed in improving this manuscript.

\section{Author's contributions}

The author read and approved the final manuscript.

\section{Availability of data and materials}

Data sharing is not applicable to this article as no datasets were generated or analysed during the current study.

\section{Competing interests}

The author declares that he has no competing interests.

Received: 23 July 2019 Accepted: 20 May 2020

Published online: 19 June 2020

\section{References}

Abouelresh, M.O., and R.M. Slatt. 2011. Shale depositional processes: Example from the Paleozoic Barnett shale, Fort Worth Basin, Texas, USA. Open Geosciences 3: 398-409. https://doi.org/10.2478/s13533-011-0037-z.

Antobreh, A.A., and S. Krastel. 2006. Morphology, seismic characteristics and development of cap Timiris canyon, offshore Mauritania: A newly discovered canyon preserved-off a major arid climatic region. Marine and Petroleum Geology 23 (1): 37-59.

Arnott, R.W.C., and B.M. Hand. 1989. Bedforms, primary structures and grain fabric in the presence of suspended sediment rain. Journal of Sedimentary Petrology 59 (6): 1062-1069.

Bagnold, R.A. 1954. Experiments on a gravity-free dispersion of large solid spheres in a Newtonian fluid under shear. Proceedings of the Royal Society of London A225: 49-63.

Bagnold, R.A. 1962. Auto-suspension of transported sediment: Turbidity currents. Proceedings of the Royal Society of London A265: 315-319.

Baker, M., J.H. Baas, J. Malarkey, R. Silva Jacinto, M. Craig, I. Kane, and S. Barker. 2017. The effect of clay type on the properties of cohesive sediment gravity flows and their deposits. Journal of Sedimentary Research 87: 1176-1195.

Banerjee, I. 1977. Experimental study on the effect of deceleration on the vertical sequence of sedimentary structures in silty sediments. Journal of Sedimentary Petrology 47 (2): 771-783.
Batalla, R.J., C. De Jong, P. Ergenzinger, and M. Sala. 1999. Field observations on hyperconcentrated flows in mountain torrents. Earth Surface Processes and Landforms 24: 247-253.

Bates, C. 1953. Rational theory of delta formation. AAPG Bulletin 37: 21192162.

Baudin, F., P. Martinez, B. Dennielou, K. Charlier, T. Marsset, L. Droz, and C. Rabouille. 2017b. Organic carbon accumulation in modern sediments of the Angola basin influenced by the Congo deep-sea fan. Deep Sea Research Part II: Topical Studies in Oceanography 142: 64-74. https://doi. org/10.1016/j.dsr2.2017.01.009

Baudin, F., E. Stetten, J. Schnyder, K. Charlier, P. Martinez, B. Dennielou, and L. Droz. 2017a. Origin and distribution of the organic matter in the distal lobe of the Congo deep-sea fan - A rock-Eval survey. Deep Sea Research Part II: Topical Studies in Oceanography 142: 75-90. https://doi. org/10.1016/j.dsr2.2017.01.008.

Beverage, J.P., and J.K. Culbertson. 1964. Hyperconcentrations of suspended sediments. Journal of the Hydraulics Division, ASCE 90: 117-128.

Bhattacharya, J.P., and J.A. McEachern. 2009. Hyperpycnal rivers and prodeltaic shelves in the cretaceous seaway of North America. Journal of Sedimentary Research 79: 184-209. https://doi.org/10.2110/jsr.2009.026.

Biscara, L., T. Mulder, P. Martinez, F. Baudin, H. Etcheber, J.M. Jouanneau, and T. Garlan. 2011. Transport of terrestrial organic matter in the Ogooué deep sea turbidite system (Gabon). Marine and Petroleum Geology 28 (5): 1061-1072.

Bouma, A.H. 1962. Sedimentology of some flysch deposits: a graphic approach to facies interpretation, 168. Amsterdam: Elsevier.

Costa, J.E. 1984. Physical geomorphology of debris flows. In Developments and Applications of Geomorphology, ed. J.E. Costa and P.J. Fleisher, 268317. Berlin: Springer.

Costa, J.E. 1986. Rheologic, geomorphic and sedimentological differentiation of water floods, hyperconcentrated flows and debris flows. In Flood Geomorphology, ed. V.R. Baker, C. Kochel, and P.C. Patton, 113-122. New York: Wiley-Interscience.

Coussot, P., and M. Meunier. 1996. Recognition, classification and mechanical description of debris flows. Earth-Science Reviews 40: 209-227.

Dasgupta, P. 2003. Sediment-gravity flow - The conceptual problems. Earth-Science Reviews 62: 265-281.

Feng, Z.Z. 2019. Words of the editor-in-chief - Some ideas about the comments and discussions of hyperpycnal flows and hyperpycnites. Journal of Palaeogeography 8 (3): 301-305.

Heezen, B.C., and C.D. Hollister. 1964. Deep sea current evidence from abyssal sediments. Marine Geology 1: 141-174.

Hollister, C.D. 1967. Sediment Distribution and Deep Circulation in the Western North Atlantic (Ph.D. dissertation), 467. New York: Columbia University.

Kuenen, P.H., and C.I. Migliorini. 1950. Turbidity currents as a cause of graded bedding. The Journal of Geology 58: 91-127.

Lash, G.G. 2016. Hyperpycnal transport of carbonaceous sediment Example from the upper Devonian Rhinestreet shale, western New York, USA. Palaeogeography, Palaeoclimatology, Palaeoecology 459: 29-43. https://doi.org/10.1016/j.palaeo.2016.06.035.

Li, J., J. Yuan, C. Bi, and D. Luo. 1983. The main features of the mudflows in Jiang-Jia ravine. Ztschrift für Geomorphologie 27: 325-341.

Lowe, D.R. 1982. Sediment gravity flows: II. Depositional models with special reference to the deposits of high-density turbidity currents. Journal of Sedimentary Petrology 52: 279-297.

Middleton, G.V. 1967. Experiments on density and turbidity currents: III. Deposition of sediment. Canadian Journal of Earth Sciences 4: 475-505.

Middleton, G.V., and M.A. Hampton. 1973. Sediment gravity flows: Mechanics of flow and deposition. In Turbidites and Deep-Water Sedimentation. SEPM, Anaheim, California Short Course Notes, ed. G.V. Middleton and A.H. Bouma, 38.

Migliorini, C.I. 1944. Sul modo di formazione dei complessi tipo macigno. Bollettino della Società Geologica Italiana 62: 48-49.

Mignard, S.L.A., T. Mulder, P. Martinez, K. Charlier, L. Rossignol, and T. Garlan. 2017. Deep-sea terrigenous organic carbon transfer and accumulation: Impact of sea-level variations and sedimentation processes off the Ogooue River (Gabon). Marine and Petroleum Geology 85: 35-53. 
Mohrig, D., K.X. Whipple, M. Hondzo, C. Ellis, and G. Parker. 1998. Hydroplaning of subaqueous debris flows. GSA Bulletin 110: 387-394.

Mulder, T., and J. Alexander. 2001. The physical character of subaqueous sedimentary density flows and their deposits. Sedimentology 48: 269-299.

Mulder, T., and E. Chapron. 2011. Flood deposits in continental and marine environments: Character and significance. In Sediment Transfer from Shelf to Deep Water - Revisiting the Delivery System, ed. R.M. Slatt and C. Zavala. AAPG Studies in Geology, vol. 61, 1-30. https://doi.org/10.1306/ $132713485 t 613436$

Mulder, T., and P. Cochonat. 1996. Classification of offshore mass movements. Journal of Sedimentary Research 66: 43-57.

Mulder, T., and J.P.M. Syvitski. 1995. Turbidity currents generated at river mouths during exceptional discharges to the world oceans. Journal of Geology 103: 285-299.

Mulder, T., J.P.M. Syvitski, S. Migeon, J.C. Faugéres, and B. Savoye. 2003. Marine hyperpycnal flows: Initiation, behavior and related deposits. A review. Marine and Petroleum Geology 20: 861-882.

Mutti, E. 1992. Turbidite sandstones, 275. San Donato Milanese: AGIP-Istituto di Geologia, Università di Parma.

Mutti, E., G. Davoli, R. Tinterri, and C. Zavala. 1996. The importance of ancient fluvio-deltaic systems dominated by catastrophic flooding in tectonically active basins. Memorie di Scienze Geologiche, Universita di Padova 48: 233-291.

Mutti, E., N. Mavilla, S. Angella, and L.L. Fava. 1999. An introduction to the analysis of ancient turbidite basins from an outcrop perspective. AAPG Continuing Education Course Note 39: 1-98.

Mutti, E., R. Tinterri, G. Benevelli, D. Di Biase, and G. Cavanna. 2003. Deltaic, mixed and turbidite sedimentation of ancient foreland basins. Marine and Petroleum Geology 20: 733-755.

Nakajima, T. 2006. Hyperpycnites deposited $700 \mathrm{~km}$ away from river mouths in the Central Japan Sea. Journal of Sedimentary Research 76 (1): 59-72.

Nemec, W. 2009. What is a hyperconcentrated flow? Conference: IAS annual meeting, Alghero (Sardinia), 20-23 September 2009. Abstracts volume.

Otharán, G., C. Zavala, M. Arcuri, M. Di Meglio, A. Zorzano, D. Marchal, and G. Köhler. 2020. Análisis de facies de fangolitas bituminosas asociadas a flujos fluidos de fango. Sección inferior de la Formación Vaca Muerta (Tithoniano), Cuenca Neuquina central, Argentina. Andean Geology 47 (2). https://doi.org/10.5027/andgeo\%25x.

Otharán, G., C. Zavala, M. Arcuri, D. Marchal, G. Köhler, M. Di Meglio, and A. Zorzano. 2018. The role of fluid mud flows in the accumulation of organic-rich shales. The upper Jurassic-lower cretaceous Vaca Muerta formation, Neuquén Basin, Argentina, 61-90. Mendoza: Congreso de Exploración y Desarrollo de Hidrocarburos, 10th, Simposio de Recursos no Convencionales, extended abstracts.

Pettijohn, F.J. 1975. Sedimentary Rocks. 3rd ed, 628. New York: Harper and Row.

Pierson, T.C. 2005. Hyperconcentrated flow - Transitional process between water flow and debris flow. In Debris-Flow Hazards and Related Phenomena, ed. M. Jakob and O. Hungr, Chapter 8, 159-202. Berlin Heidelberg: Springer.

Pierson, T.C., and J.C. Costa. 1987. A rheologic classification of subaerial sediment-water fows. In Debris flows/avalanches: Process, Recognition and Mitigation. GSA Reviews in Engineering Geology, ed. J.E. Costa and G. F. Wieczorek, vol. 7, 1-12.

Pierson, T.C., and K.M. Scott. 1985. Downstream dilution of a lahar: Transition from debris flow to hyperconcentrated streamflow. Water Resources Research 21 (10): 1511-1524.

Prior, D.B., B.D. Bornhold, and M.W. Johns. 1984. Depositional characteristics of a submarine debris flow. Journal of Geology 29: 707-727.

Sanders, J.E. 1965. Primary sedimentary structures formed by turbidity currents and related sedimentation mechanisms. In Primary Sedimentary Structures and Their Hydrodinamic Interpretation, SEPM Special Publications, ed. G.V. Middleton, vol. 12, 192-219.

Sawyer, E.W. 1986. The influence of source rock type, chemical weathering and sorting on the geochemistry of clastic sediments from the Quetico Metasedimentary Belt, Superior Province, Canada. Chemical Geology 55 (1-2): 77-95.
Schieber, J., J.B. Southard, and A. Schimmelmann. 2010. Lenticular shale fabrics resulting from intermittent erosion of water-rich muds: Interpreting the rock record in the light of recent flume experiments. Journal of Sedimentary Research 80: 119-128. https://doi.org/10.2110/jsr. 2010.005.

Schumm, S.A. 1977. The Fluvial System, 338. New York: Wiley.

Smith, G.A. 1986. Coarse grained nonmarine volcaniclastic sediment terminology and depositional process. GSA Bulletin 97: 1-10.

Smith, G.A., and D.R. Lowe. 1991. Lahars volcano hydrologic events and deposition in the debris flow hyperconcentrated flow continuum. Sedimentation in Volcanic Settings. SEPM Special Publications 45: 59-70.

Soyinka, O.A., and R.M. Slatt. 2008. Identification and micro-stratigraphy of hyperpycnites and turbidites in cretaceous Lewis shale, Wyoming. Sedimentology 55 (5): 1117-1133. https://doi.org/10.1111/j.1365-3091. 2007.00938.x.

Sparks, R.S.J., R.T. Bonnecaze, H.E. Huppert, J.R. Lister, M.A. Hallworth, J. Phillips, and H. Mader. 1993. Sediment-laden gravity currents with reversing buoyancy. Earth and Planetary Science Letters 114: 243-257.

Sumner, E.J., L.A. Amy, and P.J. Talling. 2008. Deposit structure and processes of sand deposition from decelerating sediment suspensions. Journal of Sedimentary Research 78 (8): 529-547.

Syvitski, J.P.M., S.D. Peckham, R.D. Hilberman, and T. Mulder. 2003. Predicting the terrestrial flux of sediment to the global ocean: A planetary perspective. Sedimentary Geology 162: 5-24.

Teichert, C. 1958. Concept of facies. AAPG Bulletin 42 (11): 2718-2744.

Weirich, F. 1989. The generation of turbidity currents by subaerial debris flows. California. GSA Bulletin 101: 278-291.

Wilson, R., and J. Schieber. 2014. Muddy prodeltaic hyperpycnites in the lower Genesee Group of Central New York, USA: Implications for mud transport in epicontinental seas. Journal of Sedimentary Research 84: 866-874. https://doi.org/10.2110/jsr.2014.70.

Wilson, R.D., and J. Schieber. 2015. Sedimentary facies and depositional environment of the middle Devonian Geneseo formation of New York, USA. Journal of Sedimentary Research 85 (11): 1393-1415. https://doi.org/ 10.2110/jsr.2015.88.

Zavala, C. 2018. Types of hyperpycnal flows and related deposits in lacustrine and marine basins. Quebec City: IAS, 20th International Sedimentological Congress, August 13-17, 2018 Abstract book.

Zavala, C., and M. Arcuri. 2016. Intrabasinal and extrabasinal turbidites: Origin and distinctive characteristics. Sedimentary Geology 337: 36-54. https://doi.org/10.1016/.j.sedgeo.2016.03.008.

Zavala, C., M. Arcuri, and L. Blanco Valiente. 2012. The importance of plant remains as a diagnostic criteria for the recognition of ancient hyperpycnites. Revue de Paléobiologie 11: 457-469.

Zavala, C., M. Arcuri, H. Gamero Diaz, and C. Contreras. 2007. The composite bed: A new distinctive feature of hyperpycnal deposition (abs.): AAPG annual convention and exhibition, v. 16, 157.

Zavala, C., M. Arcuri, H. Gamero, C. Contreras, and M. Di Meglio. 2011. A genetic facies tract for the analysis of sustained hyperpycnal flow deposits. In Sediment Transfer from Shelf to Deep Water — Revisiting the Delivery System, ed. R.M. Slatt and C. Zavala. AAPG Studies in Geology, vol. 61, 31-51.

Zavala, C., L. Blanco Valiente, and Y. Vallez. 2008. The origin of lofting rhythmites. Lessons from thin sections. AAPG Hedberg conference "sediment transfer from shelf to Deepwater - Revisiting the delivery mechanisms". March 3-7, 2008-Ushuaia-Patagonia, Argentina (http:// www.searchanddiscovery.com/pdfz/documents/2008/jw0807zavala/ images/jw0807zavala.pdf.html).

Zavala, C., and S.X. Pan. 2018. Hyperpycnal flows and hyperpycnites: Origin and distinctive characteristics. Lithologic Reservoirs 30 (1): 1-27.

Zavala, C., J. Ponce, D. Drittanti, M. Arcuri, H. Freije, and M. Asensio. 2006. Ancient lacustrine hyperpycnites: A depositional model from a case study in the Rayoso formation (cretaceous) of west-Central Argentina. Journal of Sedimentary Research 76: 41-59.

\section{Publisher's Note}

Springer Nature remains neutral with regard to jurisdictional claims in published maps and institutional affiliations. 